\title{
Seasonal Variability and Vertical Distribution of Autotrophic and Heterotrophic Picoplankton in the Central Red Sea
}

\author{
Najwa Al-Otaibi ${ }^{1}$, Tamara M. Huete-Stauffer ${ }^{1}$, Maria Li. Calleja ${ }^{2}$, Xabier Irigoien ${ }^{3,4}$, Xosé Anxelu G. Morán ${ }^{\text {Corresp. } 1}$ \\ ${ }^{1}$ Red Sea Research Center (RSRC), Division of Biological and Environmental Sciences and Engineering, King Abdullah University of Science and \\ Technology (KAUST), Thuwal, Saudi Arabia \\ 2 Department of Climate Geochemistry, Max Planck Institute for Chemistry (MPIC), Mainz, Germany \\ 3 AZTI - Marine Research, Pasaia, Spain \\ ${ }^{4}$ Basque Foundation for Science, IKERBASQUE, Bilbao, Spain \\ Corresponding Author: Xosé Anxelu G. Morán \\ Email address: xelu.moran@kaust.edu.sa
}

The Red Sea is characterized by higher temperatures and salinities than other oligotrophic tropical regions. Here, we investigated the vertical and seasonal variations in the abundance and biomass of autotrophic and heterotrophic picoplankton. Using flow cytometry, we consistently observed five groups of autotrophs [Prochlorococcus, two populations of Synechococcus separated by their relative phycoerythrin fluorescence, low (LF-Syn) and high (HF-Syn), and two differently-sized groups of picoeukaryotes, small (Speuk) and large (Lpeuk)] and two groups of heterotrophic prokaryotes of low and high nucleic acid content (LNA and HNA, respectively). Samples were collected in 15 surveys conducted from 2015 to 2017 at a 700-m depth station in the central Red Sea. Surface temperature ranged from 24.6 to $32.6^{\circ} \mathrm{C}$ with a constant value of $21.7^{\circ} \mathrm{C}$ below $200 \mathrm{~m}$. Integrated $(0-100 \mathrm{~m})$ chlorophyll a concentrations were low, with maximum values in fall $\left(24.0 \pm 2.7 \mathrm{mg} \mathrm{m}^{-2}\right)$ and minima in spring and summer $\left(16.1 \pm 1.9\right.$ and $1.1 \mathrm{mg} \mathrm{m}^{-2}$, respectively). Picoplankton abundance was generally lower than in other tropical environments. Vertical distributions differed for each group, with Synechococcus and LNA prokaryotes more abundant at the surface while Prochlorococcus, picoeukaryotes and HNA prokaryotes peaked at the deep chlorophyll maximum, located between 40 and $76 \mathrm{~m}$. Surface to $100 \mathrm{~m}$ depth-weighted abundances exhibited clear seasonal patterns for Prochlorococcus, with maxima in summer $\left(7.83 \times 10^{4}\right.$ cell $\mathrm{mL}^{-1}$, July 2015$)$ and minima in winter $\left(1.39 \times 10^{4}\right.$ cell $\mathrm{mL}^{-1}$, January 2015$)$. LF-Syn $\left(0.32-2.70 \times 10^{4}\right.$ cell $\left.\mathrm{mL}^{-1}\right)$, HF-Syn $\left(1.11-3.20 \times 10^{4}\right.$ cell $\left.\mathrm{mL}^{-1}\right)$ and Speuk $\left(0.99-4.81 \times 10^{2}\right.$ cell $\left.\mathrm{mL}^{-1}\right)$ showed an inverse pattern to Prochlorococcus, while Lpeuk $\left(0.16-7.05 \times 10^{4}\right.$ cell $\left.\mathrm{mL}^{-1}\right)$ peaked in fall. Synechococcus unexpectedly outnumbered Prochlorococcus in winter and at the end of 
fall. The seasonality of heterotrophic prokaryotes $\left(2.29-4.21 \times 10^{5}\right.$ cell $\left.\mathrm{mL}^{-1}\right)$ was less noticeable than autotrophic picoplankton. The contribution of HNA cells was generally low in the upper layers, ranging from $36 \%$ in late spring and early summer to ca. $48-51 \%$ in winter and fall. Autotrophs dominated integrated picoplankton biomass in the upper 100 $\mathrm{m}$, with 1.4-fold higher values in summer than in winter (mean 387 and $272 \mathrm{mg} \mathrm{C} \mathrm{m}^{-2}$, respectively). However, when the whole water column was considered, the biomass of heterotrophic prokaryotes exceeded that of autotrophic picoplankton with an average of $411 \mathrm{mg} \mathrm{C} \mathrm{m}^{-2}$. Despite being located in tropical waters, our results show that the picoplankton community seasonal differences in the central Red Sea are not fundamentally different from higher latitude regions. 


\section{Seasonal Variability and Vertical Distribution of}

2 Autotrophic and Heterotrophic Picoplankton in the Central

\section{Red Sea}

4 Najwa Al-Otaibi ${ }^{1}$, Tamara M. Huete-Stauffer ${ }^{1}$, Maria L. Calleja ${ }^{3}$, Xabier Irigoien ${ }^{4,5}$, Xosé

5 Anxelu G. Morán ${ }^{1}$

6

$7 \quad{ }^{1}$ Red Sea Research Center (RSRC), Division of Biological and Environmental Sciences and

8 Engineering, King Abdullah University of Science and Technology (KAUST), Thuwal 23955-

9 6900, Saudi Arabia

$10{ }^{3}$ Department of Climate Geochemistry, Max Planck Institute for Chemistry (MPIC), Hahn-

11 Meitner-Weg 1, 55128 Mainz, Germany

$12{ }^{4}$ AZTI - Marine Research, Herrera Kaia, Portualdea z/g -Pasaia (Gipuzkoa) 20110, Spain

13 5 IKERBASQUE, Basque Foundation for Science, Bilbao, Spain

14

15 Corresponding Author:

16 Xosé Anxelu G. Morán ${ }^{1}$

17 King Abdullah University of Science and Technology (KAUST), Thuwal 23955-6900, Saudi

18 Arabia

19 Email address: xelu.moran@kaust.edu.sa 
20

21

22

23

24

25

26

27

28

29

30

31

32

33

34

35

36

37

38

39

40

41

42

43

44

45

46

47

48

49

50

51

52

53

54

\section{Abstract}

The Red Sea is characterized by higher temperatures and salinities than other oligotrophic tropical regions. Here, we investigated the vertical and seasonal variations in the abundance and biomass of autotrophic and heterotrophic picoplankton. Using flow cytometry, we consistently observed five groups of autotrophs [Prochlorococcus, two populations of Synechococcus separated by their relative phycoerythrin fluorescence, low (LF-Syn) and high (HF-Syn), and two differently-sized groups of picoeukaryotes, small (Speuk) and large (Lpeuk)] and two groups of heterotrophic prokaryotes of low and high nucleic acid content (LNA and HNA, respectively). Samples were collected in 15 surveys conducted from 2015 to 2017 at a 700-m depth station in the central Red Sea. Surface temperature ranged from 24.6 to $32.6^{\circ} \mathrm{C}$ with a constant value of $21.7^{\circ} \mathrm{C}$ below 200 $\mathrm{m}$. Integrated $(0-100 \mathrm{~m})$ chlorophyll $a$ concentrations were low, with maximum values in fall $\left(24.0 \pm 2.7 \mathrm{mg} \mathrm{m}^{-2}\right)$ and minima in spring and summer $\left(16.1 \pm 1.9\right.$ and $1.1 \mathrm{mg} \mathrm{m}^{-2}$, respectively). Picoplankton abundance was generally lower than in other tropical environments. Vertical distributions differed for each group, with Synechococcus and LNA prokaryotes more abundant at the surface while Prochlorococcus, picoeukaryotes and HNA prokaryotes peaked at the deep chlorophyll maximum, located between 40 and $76 \mathrm{~m}$. Surface to $100 \mathrm{~m}$ depth-weighted abundances exhibited clear seasonal patterns for Prochlorococcus, with maxima in summer (7.83 $\times 10^{4}$ cell mL $\mathrm{mL}^{-1}$, July 2015$)$ and minima in winter $\left(1.39 \times 10^{4}\right.$ cell $\mathrm{mL}^{-1}$, January 2015$)$. LF-Syn $\left(0.32-2.70 \times 10^{4}\right.$ cell $\left.\mathrm{mL}^{-1}\right)$, HF-Syn $\left(1.11-3.20 \times 10^{4} \mathrm{cell} \mathrm{mL}^{-1}\right)$ and Speuk $\left(0.99-4.81 \times 10^{2}\right.$ cell $\left.\mathrm{mL}^{-1}\right)$ showed an inverse pattern to Prochlorococcus, while Lpeuk $\left(0.16-7.05 \times 10^{4}\right.$ cell $\mathrm{mL}^{-1}$ ) peaked in fall. Synechococcus unexpectedly outnumbered Prochlorococcus in winter and at the end of fall. The seasonality of heterotrophic prokaryotes $\left(2.29-4.21 \times 10^{5}\right.$ cell $\left.\mathrm{mL}^{-1}\right)$ was less noticeable than autotrophic picoplankton. The contribution of HNA cells was generally low in the upper layers, ranging from $36 \%$ in late spring and early summer to ca. $48-51 \%$ in winter and fall. Autotrophs dominated integrated picoplankton biomass in the upper $100 \mathrm{~m}$, with 1.4-fold higher values in summer than in winter (mean 387 and $272 \mathrm{mg} \mathrm{C} \mathrm{m}^{-2}$, respectively). However, when the whole water column was considered, the biomass of heterotrophic prokaryotes exceeded that of autotrophic picoplankton with an average of $411 \mathrm{mg} \mathrm{C} \mathrm{m}^{-2}$. Despite being located in tropical waters, our results show that the picoplankton community seasonal differences in the central Red Sea are not fundamentally different from higher latitude regions.

Keywords: Red Sea, Prochlorococcus, Synechococcus, picoeukaryotes, heterotrophic bacteria, high nucleic acid, low nucleic acid, flow cytometry 
55

56

57

58

59

60

61

62

63

64

65

66

67

68

69

70

71

72

73

74

75

76

77

78

79

80

81

82

83

84

85

86

87

88

89

90

91

92

93

94

\section{Introduction}

Picoplankton comprises both autotrophic and heterotrophic unicellular organisms in the size range of 0.2 to $2 \mu \mathrm{m}$. Picocyanobacteria of the genera Prochlorococcus (typically $0.6-0.8$ $\mu \mathrm{m}$ in diameter) and Synechococcus (ca. $1 \mu \mathrm{m}$ ) usually dominate numerically autotrophic picoplankton, which also includes a high diversity of picoeukaryotes larger than $1 \mu \mathrm{m}$ (Campbell et al. 1997; Giovannoni \& Vergin 2012). Prochlorococcus is usually more abundant than Synechococcus in highly stratified and low-nutrient surface waters (DuRand et al. 2001; Giovannoni \& Vergin 2012; Olson et al. 1990; Zubkov et al. 2000; Zwirglmaier et al. 2007). Picoeukaryotes are less abundant than picocyanobacteria (Kirkham et al. 2013), especially in the tropical and subtropical oceans (Kirkham et al. 2013; Morán et al. 2004). Heterotrophic picoplankton are mostly prokaryotes, overwhelmingly dominated by bacteria over archaea in the upper layers since the abundance of the latter only increases significantly at depth (Karner et al. 2001). Two flow cytometric populations of heterotrophic prokaryotes are typically detected after staining with DNA-binding dyes: high (HNA) and low (LNA) nucleic acid content cells (Gasol et al. 1999; Li et al. 1995; Nishimura et al. 2005; Sherr et al. 2006). The HNA group typically dominates in eutrophic and mesotrophic conditions characterizing the colder, nutrient-rich months while LNA tends to dominate in stratified oligotrophic environments (Calvo-Díaz \& Morán 2006; Morán et al. 2007; Zubkov et al. 2004).

Seasonal changes in the abundance of autotrophic picoplankton groups are well known in temperate (Calvo-Díaz \& Morán 2006; Li 1998; Moran 2007) and polar waters (Iversen \& Seuthe 2011; Rivkin 1991) while they are less known in lower latitude waters, with the exception of two long-term sites: the Bermuda Atlantic Time Series (BATS) in the western Sargasso Sea (DuRand et al. 2001; Malmstrom et al. 2010) and the Hawaii Ocean Time-series (HOT) in the North Pacific subtropical gyre (Campbell et al. 1997; Malmstrom et al. 2010). In contrast to autotrophs, the seasonality of heterotrophic bacteria in subtropical and tropical waters is thought to be less pronounced than in temperate regions (Bunse \& Pinhassi 2017).

The Red Sea is an oligotrophic marine basin with very high temperatures (up to $35^{\circ} \mathrm{C}$ at the surface in summer, Calbet et al. 2015; Chaidez et al. 2017; Rasul et al. 2015) and salinities (ca. 40, Tesfamichael \& Pauly 2016). The effect of these quasi-extreme conditions on the seasonality of picoplankton communities has received far less attention than other oligotrophic waters. Understanding the temporal changes of picoplankton abundance and their response to environmental drivers are essential to define the lower trophic levels of Red Sea pelagic food webs. Regarding autotrophs, we have a good understanding of their seasonal variability (AlNajjar et al. 2007; Lindell \& Post 1995; Post et al. 2011) and their trophic relationships with other components of the microbial food web in the northern reaches, especially in the Gulf of Aqaba (Berninger \& Wickham 2005; Sommer 2000; Sommer et al. 2002). For heterotrophic prokaryotes, although our knowledge about their diversity is increasing (Ngugi et al. 2012; Pearman et al. 2017; Thompson et al. 2017), only a few studies have investigated their vertical distribution in Red Sea waters (Calbet et al. 2015; Qian et al. 2011). A recent report using data collected from the same site as this study has shown that the abundance of heterotrophic bacteria 
95 can change temporally up to 3-fold within the same depth in the upper epipelagic (Calleja et al. 96 2019; García et al. 2018). Other studies conducted at that site have shown that LNA bacteria 97 dominated in the epipelagic layer, while HNA cells were more abundant in the mesopelagic 98 layer, indicating that each group seems to prefer different environmental conditions (Calleja et 99 al. 2019; Calleja et al. 2018). The unexpectedly low standing stocks of heterotrophic bacteria in a 100 nearby shallow embayment have been explained by strong top-down control exerted by protistan 101 grazers and viruses (Sabbagh et al. submitted; Silva et al. 2019).

102 Here, we conducted a detailed investigation of both the temporal and vertical variability 103 of autotrophic and heterotrophic picoplankton, as assessed by flow cytometry, by periodic 104 sampling over two years (2015-2017) at a mesopelagic station (ca. $700 \mathrm{~m}$ depth) in the central 105 Red Sea, Saudi Arabia. Given the tropical characteristics of the site, we hypothesize that the 106 seasonal variability of picoplankton in epipelagic waters would be lower than that found at 107 higher latitudes, and the marked stratification found between 100 and $200 \mathrm{~m}$ should result in 108 strong vertical gradients in abundance, size and ultimately biomass. 
109 Materials \& Methods

\section{Sample collection and environmental properties}

111 Periodic samplings were conducted from January 2015 to May 2017 on board of RV

112 Thuwal at a mesopelagic station (ca. $700 \mathrm{~m}$ depth) located in the central Red Sea, $6 \mathrm{~km}$ off the

113 coast of King Abdullah Economic City (KAEC) in Saudi Arabia. Sailing permission were

114 approved by Saudi Coast Guard. We performed 15 vertical profiles evenly distributed along the

115 four seasons (only winter had 3 samples rather than 4, Table 1). Samples were taken at regular

116 depths from the surface to the bottom: 5, 20, 40-80 targeting the deep chlorophyll maximum

117 (DCM), 100, 200, 300, 400, 550, 600 and $700 \mathrm{~m}$. Temperature, salinity, fluorescence and

118 photosynthetically active radiation (PAR) data were acquired with SeaBird SB9 Plus or

119 IDRONAUT 305 CTDs. PAR was available for only 7 sampling times. The depth of the photic

120 layer was determined by the vertical light attenuation coefficient $(\mathrm{Kd})$ as the depth receiving $1 \%$

121 of surface irradiance (Calvo-Díaz \& Morán 2006). Stratification index (SI) was calculated as the

122 density at $100 \mathrm{~m}$ minus that at the surface (Calvo-Díaz \& Morán 2006). The upper mixed layer

123 (UML) depth was determined as the first depth in which the difference in density with the

124 shallower $5 \mathrm{~m}$ was $\geq 0.05 \mathrm{~kg} \mathrm{~m}^{-3}$ (Calvo-Díaz \& Morán 2006).

125 Water samples were taken from Niskin bottles in a rosette sampler with an attached CTD

126 probe (Fig. S1). In 2015 total chlorophyll $a$ concentration (Chl $a$ ) was obtained after filtering 500

127 to $2000 \mathrm{ml}$ of the sample through Whatman GF/F filters (25 mm diameter). After checking for

128 the minimum volume yielding reliable results, in 2016 and 2017 we performed sequential

129 filtration of $200 \mathrm{ml}$ samples through filters of 20,2 and $0.2 \mu \mathrm{m}$ of pore-size (IsoporeTM

130 Membrane Filters, RTTP, $47 \mathrm{~mm}$ diameter), so that Chl $a$ was the sum of the corresponding size-

131 fractions: micro- (above $20 \mu \mathrm{m}$ ), nano- (between 2 and 20) and picophytoplankton (between 0.2

132 and $2 \mu \mathrm{m})$. Filters were frozen at $-80{ }^{\circ} \mathrm{C}$ until analysis in the laboratory. Pigments were extracted

133 in $90 \%$ acetone for $24 \mathrm{~h}$ in the dark at $4^{\circ} \mathrm{C}$ and chlorophyll $a$ fluorescence was measured with a

134 Trilogy fluorometer (Turner) calibrated with pure extracts.

135 Samples for dissolved inorganic nitrogen $\left(\mathrm{DIN}=\mathrm{NO}^{3-}+\mathrm{NO}^{2-}\right)$, dissolved inorganic

136 phosphorus (DIP $=\mathrm{PO}_{4}{ }^{3-}$ ), dissolved organic carbon (DOC) and total dissolved nitrogen (TDN)

137 were filtered through pre-combusted GF/F filters and analyzed as previously reported by (Calleja

138 et al. 2018). The nutricline depth was defined as the depth where nitrate concentration first

139 reached $1 \mu \mathrm{mol} \mathrm{L}{ }^{-1}$ (Calvo-Díaz \& Morán 2006).

140

141 Analysis of picoplankton by flow cytometry

142 Picoplankton samples $(1.8 \mathrm{~mL})$ were preserved with $1 \%$ paraformaldehyde $+0.05 \%$

143 glutaraldehyde final concentration and placed in the dark for approximately 10 minutes, then

144 frozen in liquid nitrogen and stored at $-80{ }^{\circ} \mathrm{C}$ once in the laboratory. After thawing, samples were

145 analyzed with a FACSCanto II flow cytometer (BD-Biosciences). Molecular Probes fluorescent

146 latex beads of $1 \mu \mathrm{m}$ were used as an internal standard for size and fluorescence measurements.

147 We analyzed aliquots of $0.6 \mathrm{~mL}$ for autotrophs and $0.4 \mathrm{~mL}$ for heterotrophs, at high (mean 117.9

$148 \mu \mathrm{L} \mathrm{m^{-1 }}$ ) and low $\left(17.9 \mu \mathrm{L} \mathrm{min}^{-1}\right)$ flow rates, respectively, until acquiring 10000 events. Before

Peer] reviewing PDF | (2019:07:39703:2:0:NEW 13 Jan 2020) 
149 analysis, heterotrophic bacteria were stained with $2.5 \mu \mathrm{mol} \mathrm{L}^{-1}$ of the DNA fluorochrome SYBR

150 Green II (Gasol \& Morán 2016). All cytograms were analyzed with FCSExpress 5 software.

151 Autotrophic prokaryotic cells were classified as cyanobacteria (Synechococcus and

152 Prochlorococcus) and picoeukaryotes according to their orange (PE, $433 \mathrm{~nm}$ ) and red (PerCP-

153 Cy5-5, $498 \mathrm{~nm}$ ) fluorescence and light scatter at $90^{\circ}$ or side scatter (SSC) signals. Two groups of

154 heterotrophic prokaryotes were distinguished based on their relative green fluorescence (FITC,

$155360 \mathrm{~nm}$ ) signal: low and high nucleic acid content (LNA and HNA, respectively). Cell size was

156 determined by an empirical calibration between relative SSC and cell diameter according to

157 (Calvo-Díaz \& Morán 2006). Spherical shape was assumed for all groups for estimating

158 biovolume, which was transformed into individual biomass by using the biovolume-to-carbon

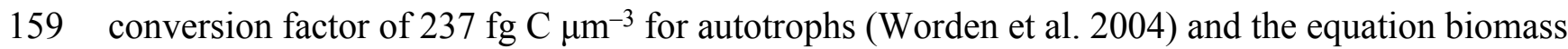

$160=108.8 \times(\text { biovolume })^{0.898}$ for heterotrophs (Gundersen et al. 2002). The biomass of each

161 picoplanktonic group was finally obtained by multiplying the individual biomass estimate by the

162 corresponding abundance.

163

\section{Statistical analyses}

Picoplankton abundance, biovolume and biomass data were $\log 10$-transformed to attain normality and assess their relationship with environmental variables by Spearman's rank correlation coefficient. One-way ANOVAs and post hoc Tukey's pairwise comparisons were used to determine significant variations between seasons $(\mathrm{P}<0.05)$ with OriginPro software. A non-metric multidimensional scaling (NMDS), a distance-based ordination technique, was performed on the Bray-Curtis dissimilarity distances together with pairwise PERMANOVAs in order to summarize the seasonal and vertical changes in the abundance of the different picoplankton groups and their relation with environmental variables in the upper epipelagic zone. Four groups of samples were considered according to depth: surface, above DCM, DCM depth, below DCM and $100 \mathrm{~m}$. NMDS stress values, a measure of goodness-of-fit, can be used to evaluate the proper choice of dimensions. Low values $(0.05-0.1)$ provide a good fit in reduced dimensions while values $>0.3$ indicate that the ordination is arbitrary and potentially uninterpretable (Ramette 2007; Zhu \& Yu 2009). The NMDS analysis was done in R (www.rproject.org) and we used the "envfit" function in order to estimate the correlations between the environmental variables and the NMDS axis scores. 
180 Results

181 Vertical and seasonal variability in hydrographic conditions

182 The mean vertical profiles of selected environmental variables for the four seasons are 183 shown in Fig. 1. As expected, significant differences (ANOVA: $F=14.4, p=0.0004, n=15$ ) in 184 mean surface temperature were found, with summer values $6.3^{\circ} \mathrm{C}$ higher than in winter (Table

185 2). The temperature remained constant year-round from $200 \mathrm{~m}$ down to the bottom at $21.7 \pm$ $1860.02^{\circ} \mathrm{C} \mathrm{SE}$ (Fig. 1A). Surface salinity displayed slight seasonal variations from $38.8 \pm 0.2$ in 187 spring to $39.6 \pm 0.1$ in winter (Table 2), but there was no seasonal difference below $200 \mathrm{~m}$ (40.6 $188 \pm 0.0$ ). Differences in SI were not significant despite some seasonality (Table 2), but the UML 189 was significantly shallower in summer than in the other seasons (Table 2, ANOVA: F=18.3, $\mathrm{p}=$ $1900.0002, \mathrm{n}=14$ ). The euphotic layer depth varied from 63 to $89 \mathrm{~m}$, with similar mean values across 191 seasons (Table 2).

192 Dissolved inorganic nitrogen $(\mathrm{DIN}=$ nitrate + nitrite $)$ presented uniformly low

193 concentrations at the surface $\left(0.17 \pm 0.11 \mu \mathrm{mol} \mathrm{L}^{-1}\right)$ but reached $20.5 \pm 1.6 \mu \mathrm{mol} \mathrm{L}^{-1}$ at depths

194 higher than $200 \mathrm{~m}$ (Fig. 1C), with an average nutricline depth of $67 \pm 6 \mathrm{~m}$ (Table 2). Dissolved 195 inorganic phosphate (DIP) followed the same pattern as DIN, with low seasonal mean values at 196 the surface $(0.10 \pm 0.04 \mu \mathrm{mol} \mathrm{L}-1)$ and increasing with depth to a seasonal mean maximum of $1971.17 \pm 0.1 \mu \mathrm{mol} \mathrm{L}-1$ at around $600 \mathrm{~m}$ depth (Fig. $1 \mathrm{D})$. The concentration of dissolved organic 198 carbon (DOC, Fig 1E) declined with depth from a mean $76.1 \pm 7.5 \mu \mathrm{mol} \mathrm{L}^{-1}$ at the surface to $19952.2 \pm 5.8 \mu \mathrm{mol} \mathrm{L}{ }^{-1}$ below $200 \mathrm{~m}$.

200

201

202

203

204

205

206

207

208

209

210

211

212

213

214

215

216

217

\section{Total and size-fractionated chlorophyll $a$ concentration}

The vertical distribution of total chlorophyll $a(\mathrm{Chl} a)$ concentration (Fig. 1F) showed a consistent and clear deep chlorophyll maximum (DCM) located at an average depth of $56 \pm 4 \mathrm{~m}$ (Table 2). Surface seasonal mean values ranged from 0.09 to $0.15 \mu \mathrm{g} \mathrm{L}-1$ (Fig. 1 F). Mean integrated $\mathrm{Chl} a$ values for the upper $100 \mathrm{~m}$ increased from $16.1 \mathrm{mg} \mathrm{m}^{-2}$ in spring and summer $( \pm$ 2.06 and 1.09 , respectively) to $19.0 \pm 2.9 \mathrm{mg} \mathrm{m}^{-2}$ in winter and $24.0 \pm 2.7 \mathrm{mg} \mathrm{m}^{-2}$ in fall (Fig. 2 A). The picoplankton size fraction contributed, on average, $70.8 \pm 1.0 \%$ to total integrated values, with nanoplankton and microplankton making up $21.9 \pm 1.5 \%$ and $7.3 \pm 1.9 \%$, respectively, with no significant differences in the relative contributions of the three size classes (Fig. 2 B).

\section{Vertical distribution of picoplankton abundance and cellular characteristics}

Prochlorococcus, Synechococcus and picoeukaryotes were mostly restricted to the upper $100 \mathrm{~m}$, with none of the groups detected in significant numbers at or below $150 \mathrm{~m}$ depth. Figure 3 shows the average vertical distribution of picophytoplankton abundance, cell size and relative red fluorescence (as a proxy of Chl $a$ content) for each season. Prochlorococcus abundance was generally low at the surface $\left(1.11-5.81 \times 10^{4}\right.$ cells $\left.\mathrm{mL}^{-1}\right)$ and peaked at the DCM $(1.32 \pm 0.16 \times$

$21810^{5}$ cells mL $\mathrm{mL}^{-1}$ in summer) (Fig. 3A). The two groups of Synechococcus discriminated by low 
219 (LF-Syn) and high (HF-Syn) phycoerythrin fluorescence were consistently less abundant than 220 Prochlorococcus. LF-Syn and HF-Syn tended to show higher numbers in the surface layers, with

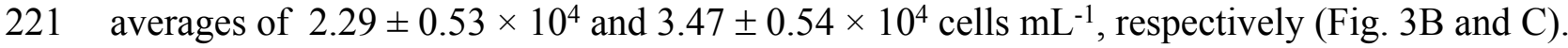
222 HF-Syn reached deeper than LF-Syn with the latter virtually absent at $80 \mathrm{~m}$ (Fig. 3B and C).

223

224

225

226

227

228

229

230

231

232

233

234

235

236

237

238

239

240

241

242

243

244

245

246

247

248

249

250

251

252

253

254

255

256

257

258

Two groups of picoeukaryotes according to size were consistently distinguished, hereafter referred to as Small (Speuk) and large (Lpeuk). Speuk vertical distribution was similar to that of Prochlorococcus (Fig. 3D), while Lpeuk usually disappeared deeper than 40-60 m except in fall, where the highest values were found in the DCM (Fig. 3D and E). Coincident with declining abundances, the biovolume of all groups increased steadily with depth from $40 \mathrm{~m}$ downwards except for Lpeuk (Fig. 3F-J). Similar to biovolume, the relative red fluorescence increased consistently with depth, with less marked patterns for LF-Syn and Lpeuk due to their shallower distribution (Fig. 3 K-O).

The mean seasonal distribution of heterotrophic prokaryotes abundance and cell size with depth is shown in Fig. 4. The abundances of both LNA and HNA cells were highest in the upper $100 \mathrm{~m}$ (maxima of $2.92 \times 10^{5}$ and $2.51 \times 10^{5}$ cells $\mathrm{mL}^{-1}$ at 20 and $40 \mathrm{~m}$, respectively) but remained relatively stable for the entire mesopelagic layer (Fig. 4A and B). LNA were more abundant than HNA cells in the upper epipelagic, resulting in a contribution of HNA cells to total abundance (\%HNA) that ranged from 38.3 to $47.1 \%$ at the surface. Values increased to 52.3 $-57.4 \%$ at $200 \mathrm{~m}$ and remained pretty homogeneous down to the sea floor (Fig. $4 \mathrm{C}$ ). The biovolume of HNA cells was consistently larger than that of LNA cells throughout the water column. Differences were observed between seasons, with maxima in winter for both groups and minima in summer for HNA and in fall for LNA cells (Fig. $4 \mathrm{D}$ and E).

\section{Seasonal variation of picoplankton abundance and cellular characteristics}

Although some differences between seasons were already apparent in the vertical distributions (Fig. 3 and 4), depth-weighted averages from the surface to $100 \mathrm{~m}$ were calculated to better capture the seasonal changes. Prochlorococcus abundance displayed a clear seasonal pattern, with minimum values in winter $\left(1.4 \times 10^{4}\right.$ cell $\mathrm{mL}^{-1}$, January 2015$)$ and maximum values in summer $\left(7.8 \times 10^{4}\right.$ cell $\mathrm{mL}^{-1}$, July 2015) (Fig. 5 A). The two groups of Synechococcus shared similar dynamics, with maximum values in spring for LF-Syn $\left(2.7 \times 10^{4}\right.$ cell $\mathrm{mL}^{-1}$, March 2015) and winter for HF-Syn $\left(3.2 \times 10^{4}\right.$ cells $\mathrm{mL}^{-1}$, January 2015) while the lowest values were observed between late spring and early summer for both groups (Fig. 5B). Consequently, the ratio between Prochlorococcus and Synechococcus abundance, which was higher than 1 for most of the year, was occasionally lower in winter and at the end of fall (Fig. 5C). Speuk abundance presented low values in summer $\left(9.9 \times 10^{2}\right.$ cells mL $\mathrm{mL}^{-1}$, July 2015) and higher in winter $(3.60 \times$ $10^{3}$ cells $\mathrm{mL}^{-1}$, January 2015) while Lpeuk, generally less abundant, peaked in fall $\left(7.1 \times 10^{2}\right.$ cells $\mathrm{mL}^{-1}$, October 2016) (Fig. 5 D). On an annual basis, Prochlorococcus contributed $57.6 \pm$ $4.2 \%$ to total picophytoplankton cell numbers, followed by Synechococcus $(38.9 \pm 3.9 \%)$ with picoeukaryotes 21- to 79-fold lower abundances than cyanobacteria. Depth-weighted biovolumes (0.14-0.25 $\mu \mathrm{m}^{3}$ Prochlorococcus, 0.08- $0.19 \mu \mathrm{m}^{3}$ LF-Syn, 0.27-0.42 $\mu \mathrm{m}^{3}$ HF-Syn, $1.09-1.66 \mu \mathrm{m}^{3}$

Peer) reviewing PDF | (2019:07:39703:2:0:NEW 13 Jan 2020) 
259 Speuk, 2.50-3.62 $\mu \mathrm{m}^{3}$ Lpeuk) did not show any clear seasonal pattern with slightly increased 260 values of Speuk in early summer and Lpeuk in fall (Fig. S2 A-C). The seasonality of 0-100 m 261 mean relative red fluorescence as a proxy for $\mathrm{Chl} a$ content followed the expected summer 262 minimum only for Prochlorococcus and LF-Syn (Fig. S2 D-F). Differences in biovolume affected little the changes mentioned above in abundance when calculating the biomass of the different picophytoplankton groups. Integrated autotrophic picoplankton biomass for the upper $100 \mathrm{~m}$ showed higher values in summer $\left(387.4 \mathrm{mg} \mathrm{C} \mathrm{m}^{-2}\right)$ with a significant contribution of Prochlorococcus $(46.6 \pm 6 \%$ ) (ANOVA: $\mathrm{F}=4.2, \mathrm{p}=0.03, \mathrm{n}=15$ ) except in winter when Synechococcus contributed $49.5 \%$ with a high contribution of HF-Syn (37.02\%).

The mean total abundance of heterotrophic prokaryotes (HNA + LNA prokaryotes) in the upper $100 \mathrm{~m}$ ranged from 2.29 to $4.21 \times 10^{5}$ cells $\mathrm{mL}^{-1}$, with higher values in spring and fall and lower in summer (Dataset S1). Figure 6A shows the corresponding values for the LNA and HNA groups with respective annual means of $1.87 \pm 0.01 \times 10^{5}$ and $1.38 \pm 0.07 \times 10^{5}$ cells $\mathrm{mL}^{-1}$. Although their abundances failed to show marked seasonal patterns, a clear seasonality in the contribution of HNA bacteria emerged. Upper epipelagic-averaged \%HNA values ranged from $35.9 \%$ in late spring and early summer to ca. $50 \%$ in winter and fall (Fig. 6 B). In contrast, the seasonality in biovolume and relative nucleic acid content was not clear for any of the two groups (Fig. S3A and B). The integrated biomass of heterotrophic prokaryotes in the upper 100 $\mathrm{m}$ ranged from 86.9 to $257.6 \mathrm{mg} \mathrm{C} \mathrm{m}^{-2}$, with seasonal means shown in Fig. 7. Regarding the contribution of LNA and HNA cells to total heterotrophic prokaryotes biomass in the upper epipelagic, differences were minor with the HNA group prevailing in winter $(53.8 \%)$ and fall $(51.3 \%)$ and the LNA groups in summer (53.4\%) and spring (52.3\%) (Fig. 7). Overall, the biomass of autotrophic picoplankton groups was consistently higher than that of heterotrophic bacteria in the upper epipelagic, with annual averages of $348.1 \pm 20.5$ and $140.8 \pm 10.1 \mathrm{mg} \mathrm{C} \mathrm{m}^{-}$ ${ }^{2}$, respectively. However, when values were integrated over the entire water column $(0-700 \mathrm{~m})$, the mean biomass of heterotrophic bacteria increased to $410.7 \pm 27.0 \mathrm{mg} \mathrm{C} \mathrm{m}^{-2}$, thus exceeding the total biomass of autotrophic picoplankton (Fig. 7). Moreover, when the entire water column was considered HNA cells clearly dominated total biomass regardless of the season.

\section{Relationships with environmental variables}

290

Fig. 8 shows the NMDS performed on the Bray-Curtis distances of the abundances for autotrophic and heterotrophic picoplankton populations at different depths in the upper epipelagic (Fig. 8). The low stress value (0.1) indicated a reliable distribution of the samples in two dimensions. All environmental variables were initially considered in the NMDS analysis, but some of them (e.g., DIP, DOC, UML, etc.) were removed since they did not show significant effects on the distribution of the samples. The correlation of the NMDS scores (position of the samples) with the environmental variables (represented by the arrows) indicated significant effects of temperature ( $\mathrm{r}=0.66, \mathrm{p}=0.002)$, DON $(\mathrm{r}=0.48, \mathrm{p}=0.034$, Chl $a(\mathrm{r}=0.62, \mathrm{p}=0.003)$, DIN $(r=0.72, p=0.001)$ and salinity $(r=0.75, p=0.001)$. The NMDS plot also showed different habitat segregation of the picoplanktonic groups, with an overall significant effect of the depth 
299 layer (PERMANOVA: $\mathrm{r}^{2}=0.53, \mathrm{p}<0.01$ ). The most abundant group in the surface was 300 Synechococcus (mostly the HF_Syn), where temperature and DON were highest. In contrast, 301 Prochlorococcus and picoeukaryotes (mainly Speuk) were more abundant around the depth of 302 the DCM, actually contributing to the increase in Chl $a$. HNA and LNA had a higher weight at $303100 \mathrm{~m}$, primarily because of the decrease in autotrophic picoplankton groups, where DIN and 304 salinity values started to increase with depth (Fig. 8). There was no significant clustering of 305 samples according to the different seasons (PERMANOVA: $\mathrm{r}^{2}=0.04, \mathrm{p}=0.33$ ), indicating that 306 the effect of depth layer was stronger than season (Fig. S4). 


\section{Discussion}

308 The Red Sea represents a unique environment to investigate how picoplankton, the 309 dominant planktonic size class at low latitudes (Buck et al. 1996; Malmstrom et al. 2010; Olson

310 et al. 1990), respond to some of the highest natural temperatures and salinities that can be found

311 in the ocean. We present here a comprehensive flow cytometric assessment of autotrophic and

312 heterotrophic groups at both the vertical and seasonal scales at a 700-m deep station in the

313 central Red Sea. Surface waters showed persistently high stratification, limiting the availability

314 of DIN and DIP, which resulted in low phytoplankton biomass for most of the year (Fig. 1F and

315 2) and a clear dominance of small cells consistent with previous work (Bock et al. 2018; van den

316 Engh et al. 2017; Wei et al. 2019). Accordingly, DOC concentrations did not exceed $95 \mu \mathrm{mol} \mathrm{L}-$

317 . More information on the hydrological features and DOC dynamics of the study site can be

318 found in Calleja et al. (2019). In the nearby shallow waters of KAUST Harbor, although

319 conditions were still oligotrophic year-round, higher concentrations of DIN and DOC were

320 occasionally observed (Silva et al. 2019).

321

322

323

324

325

326

327

328

329

330

331

332

333

334

335

336

337

338

339

340

341

342

343

344

345

346

\section{Vertical distribution of picoplankton}

In this study, although cyanobacteria and picoeukaryotes made up most of the picophytoplankton biomass as chlorophyll $a$ (Fig. 2 B), different depth preferences for each group were found. Prochlorococcus and the two size fractions of picoeukaryotes tended to show higher abundances at a depth of the DCM, which ranged from 40 to $76 \mathrm{~m}$, than at the surface where both groups of Synechococcus peaked (Fig. 3 A-E). This distribution was further confirmed by the NMDS analysis of all samples (Fig. 8), showing a clear cluster of surface samples (with higher temperatures and DON) dominated by Synechococcus, while Prochlorococcus and picoeukaryotes dominated the DCM. This vertical segregation of Prochlorococcus and Synechococcus is well known (Partensky et al. 1999; Rabouille et al. 2007) and indicates a different adaptation to ambient light conditions. The light-harvesting antenna of Synechococcus have phycobilisomes with phycobiliproteins (phycoerythrin and phycocyanin) that confer them a higher ability to stand the high irradiances (including UV wavelengths) found at the surface (Biller et al. 2015). Several studies have suggested that Prochlorococcus is more sensitive to sunlight, particularly to UV potentially causing DNA-damage, than Synechococcus (Agustí 2004; Boelen et al. 2000; Boelen et al. 2002). Accordingly, Prochlorococcus is better adapted to capture the blue wavelengths that predominate deeper in the water column (Biller et al. 2015), thus giving rise to the observed differences in vertical distribution. However, the maximum depth at which we were able to detect cyanobacteria and picoeukaryotes by flow cytometry was generally $100 \mathrm{~m}$. Molecular analysis is more sensitive than flow cytometry at finding rare populations. A recent study in the Red Sea assessing 16S rRNA gene sequences, more sensitive than flow cytometry, was able to find Prochlorococcus below $200 \mathrm{~m}$, though with low numbers (Shibl et al. 2016). In other studies conducted in tropical waters, Prochlorococcus and Synechococcus were, however, detected by flow cytometry at depths of 150 to $200 \mathrm{~m}$ (Bock et al. 2018; Partensky et al. 1999; van den Engh et al. 2017). The flow cytometer used in this 
347 study has a high sensitivity to detect small cells $(<1 \mu \mathrm{m})$ and viruses (Monier et al. 2017). Thus, 348 we believe that the apparent disappearance of picophytoplankton at those depths is rather a

349

350

351

352

353

354

355

356

357

358

359

360

361

362

363

364

365

366

367

368

369

370

371

372

373

374

375

376

377

378

379

380

381

382

383

384

385 reflection of the already low numbers found in shallower depths compared with other studies than a problem with the detection limit (Ribeiro et al. 2016). Bearing in mind that 15 profiles along the annual cycle might still have missed the period of highest concentration, to our knowledge, the maximum abundance observed of Prochlorococcus $\left(1.63 \times 10^{5}\right.$ cells ml-1 $)$ lies among the lowest ever recorded. For instance, the maximum values in the subtropical and tropical oceans found during the Malaspina-2010 expedition were $14.2 \times 10^{5}$ cells ml $^{-1}$ for the Atlantic, $6.35 \times 10^{5}$ cells ml-1 for the Indian and $3.27 \times 10^{5}$ cells ml$^{-1}$ for the Pacific (Agustí et al. 2018). The mean abundance of Synechococcus at the study site was also lower $\left(1.16 \times 10^{4}\right.$ cells $\left.\mathrm{ml}^{-1}\right)$ than in the Indian $\left(2.34 \times 10^{4}\right.$ cells ml$\left.^{-1}\right)$ and Pacific $\left(4.85 \times 10^{4}\right.$ cells ml-1 $)$ oceans, but higher than in the Atlantic $\left(0.87 \times 10^{4}\right.$ cells ml-1 $)$. Very low abundances of picoeukaryotes were also consistently found in this study $\left(9.7 \times 10^{3}\right.$ cells $\left.\mathrm{ml}^{-1}\right)$ compared to the Atlantic $(18.5 \times$ $10^{3}$ cells ml-1), Indian $\left(16.7 \times 10^{3}\right.$ cells ml$\left.{ }^{-1}\right)$ and Pacific $\left(79.3 \times 10^{3}\right.$ cells ml $\left.{ }^{-1}\right)$ oceans (Agustí et al. 2018). As in previous reports, consistent associations between the decrease in abundance and the increase in cell size and relative red fluorescence were observed for all picophytoplankton groups except for large picoeukaryotes (Fig. 3 F-O). This increase should be primarily attributed to the combined effects of depth-varying environmental variables such as inorganic nutrients availability and light (Chen et al. 2011), although shifts in species composition may also play a role (Campbell \& Vaulot 1993). The decrease in irradiance drives the need to synthesize more proteins and pigments to capture the fewer photons reaching the deeper layers (van den Engh et al. 2017).

Regarding the vertical distribution of heterotrophic prokaryotes, we confirm the findings of two recent studies conducted at the same site as ours, focused on the interactions of bacteria with DOC stocks at the diel (García et al. 2018) and seasonal scales (Calleja et al. 2019). As previously reported (Calleja et al. 2019; García et al. 2018), LNA bacteria dominated in the epipelagic zone while HNA bacteria prevailed in the mesopelagic zone. The lower relative numbers of HNA cells in the upper $100 \mathrm{~m}$ (usually below 51\%) could be explained by the presence of protistan grazers with a preference for the larger HNA cells (Gonzalez et al. 1990; Lefort \& Gasol 2014). Recent work has shown that the abundances of heterotrophic nanoflagellates were negatively correlated with the sizes of both LNA and HNA cells, suggesting a preference to graze on the larger cells from both groups (Sabbagh et al., submitted). In turn, the dominance of HNA cells in the whole mesopelagic layer suggests either a release from grazing pressure (Lara et al. 2017) or that different taxa belonging to the HNA cluster are better suited to exploit the DOC compounds found at depth (Calleja et al. 2019). The mesopelagic zone in this Red Sea site is characterized by a deep scattering layer, located between 400 and $600 \mathrm{~m}$, where vertically migrating fish concentrate during the day (Calleja et al. 2018; Røstad et al. 2016). This layer seems to play an essential role in fast carbon transport and cycling by heterotrophic prokaryotes, as shown in previous studies (Calleja et al. 2019; García et al. 2018). 
386

387

388

389

390

391

392

393

394

395

396

397

398

399

400

401

402

403

404

405

406

407

408

409

410

411

412

413

414

415

416

417

418

419

420

421

422

423

424

425

Overall, the vertical distribution of picoplankton was most clearly affected by depth, in turn related to strong gradients in environmental variables (temperature, light, UV, inorganic nutrients, etc.), as clearly observed in the NMDS distribution of samples (Fig. 7) that cluster according to layer much more obviously than to season (Fig. S4). However, seasonal patterns became more evident when considering the depth-averaged or integrated values, as discussed below.

\section{Seasonal variation of picoplankton}

Except at very high latitudes (Cottrell \& Kirchman 2009; Li 2009; Waleron et al. 2007), cyanobacteria numerically dominate picophytoplankton communities, although the prevailing genus depends on the specific physicochemical properties and trophic structure. The dominance of Prochlorococcus has been frequently observed in high temperature, low nutrient and stratified waters, while Synechococcus and picoeukaryotes are usually predominant at lower temperatures, higher nutrient concentrations and more mixed waters (Campbell et al. 1997; Malmstrom et al. 2010). It has been hypothesized that the seasonality of picoplankton groups in tropical and subtropical oceans is less pronounced than in temperate or polar regions (Bunse \& Pinhassi 2017). However, although our site can be safely considered as permanently oligotrophic since it is strongly stratified year-round, surface temperature did indeed change between seasons (Table 2). On an annual scale, the longest subtropical time series at BATS displays high abundance of Prochlorococcus in summer and fall due to strong stratification and low values in late winter due to deep mixing events, while this pattern is much less visible at HOT (Campbell et al. 1997; DuRand et al. 2001; Giovannoni \& Vergin 2012; Malmstrom et al. 2010). A similar seasonal variability has also been reported in the Gulf of Aqaba in the northern Red Sea (Al-Najjar et al. 2007). However, two major differences were observed in this study. In spite of the overall dominance of Prochlorococcus especially noticeable in summer, Synechococcus unexpectedly outnumbered Prochlorococcus in winter and fall in the epipelagic layer (Fig. 5C). The fact that two populations of Synechococcus of differing orange fluorescence, LF-Syn and HF-Syn, were consistently found year-round did not result in major divergences in seasonality (Fig. 5B). Altogether, the total abundance of Synechococcus at our site peaked in winter the same as at HOT station (Campbell et al. 1997; Malmstrom et al. 2010), while the maximum abundance at BATS was found during the spring bloom when the mixed layer deepened and inorganic nutrients were detectable in surface layers (DuRand et al. 2001). Picoeukaryotes have been reported to be more abundant in spring at both sites (Campbell et al. 1997; DuRand et al. 2001). In our dataset, although the two size fractions demonstrated different seasonality, picoeukaryotes generally tended to peak either at the beginning (winter-spring) or the end of the year (fall) (Fig. 5 D).

With complete seasonal coverage, we confirm the finding that LNA heterotrophic prokaryotes dominate in the upper epipelagic $(<100 \mathrm{~m})$ while their HNA counterparts prevail in the mesopelagic zone ( $\geq 200 \mathrm{~m}$ ) (García et al. 2018). Heterotrophic bacteria and archaea have been reported to present higher abundances in summer and decline in fall at BATS (Carlson et al. 
426

427

428

429

430

431

432

433

434

435

436

437

438

439

440

441

442

443

444

445

446

447

448

449

450

451

452

453

454

455

456

457

458

459

460

461

462

463

464

1996) while the peak at HOT occurred in summer-fall (Campbell et al. 1997). In this study, the seasonality of both the LNA and HNA groups, as well as their sum, was less noticeable than autotrophic picoplankton, though low numbers were mostly observed in summer, as already reported by Calleja et al. (2019). Bottom-up control by phosphorus could partially explain the decrease of heterotrophic prokaryotes in summer in the upper $100 \mathrm{~m}$. Calleja et al. (2019) reported that epipelagic DIN:DIP ratios (without ammonium) peaked at 19 during summer, while lower values of ca. 11 were observed during the rest of the year, concomitant with DOC accumulation that could be a consequence of nutrient-limited and low standing stocks. Concurrently, in the experimental assessment of specific growth rates in the shallow waters of KAUST Harbor, top-down control by protistan grazers has been demonstrated to play an important role in regulating heterotrophic prokaryotes standing stocks (Silva et al. 2019).

There is little information about primary productivity (Qurban et al. 2019) and planktonic metabolism (López-Sandoval et al. 2019) in the Red Sea to allow an assessment of the seasonality of its metabolic balance (i.e., the periods of net autotrophy vs. net heterotrophy, García-Martín et al. 2019a; García-Martín et al. 2019b). We can still compare the respective biomasses of autotrophs and heterotrophs within the smaller size fraction, which collectively support to a large extent the higher trophic levels in oligotrophic environments. The relative importance of heterotrophic prokaryotes biomass to total planktonic biomass has been shown to increase with decreasing trophic state (Azam 1998; Biddanda et al. 2001; Del Giorgio et al. 1997; Gasol et al. 1997), with an average ratio of 1.85 in the oligotrophic ocean (Buck et al. 1996; Cho \& Azam 1990; Gasol et al. 1997). Considering only picoplankton, autotrophic cells make a higher contribution to total biomass in meso- to eutrophic areas, while heterotrophic bacteria and archaea typically become more important in tropical and subtropical oligotrophic oceans (Harris et al. 2006; Regaudie-de-Gioux \& Duarte 2013; Zhang et al. 2008). If we restrict our analysis to the first $100 \mathrm{~m}$, autotrophic picoplankton biomass consistently exceeded that of heterotrophic prokaryotes biomass (Fig. 7), suggesting that the upper central Red Sea would be a net autotrophic ecosystem over the entire annual cycle (i.e., primary production would exceed community respiration), in agreement with the recent study of López-Sandoval et al. (2019). The major contributor to autotrophic picoplankton biomass was Prochlorococcus as in other oligotrophic waters (Wei et al. 2019; Zhang et al. 2008), except in winter. However, if we extend the comparison between autotrophic and heterotrophic picoplankton biomass to the bottom of the study site, the ecosystem would then tend to net heterotrophic, but this difference was not very marked (Fig. 7). It is noteworthy that KAEC station lies between the metabolically balanced or net heterotrophic in the northern Red Sea and the net autotrophic waters of its southern reaches (López-Sandoval et al. 2019). In any case, further studies are necessary to fully understand the functioning of the central Red Sea pelagic ecosystem by a comprehensive assessment of its matter and energy fluxes.

This flow cytometry-based study is the first detailed temporal account of picoplankton abundance, single-cell characteristics and biomass covering from epi- to mesopelagic waters ever 
465 conducted in the central Red Sea. Future studies of the variations occurring at the daily scale will 466 help interpret the seasonal patterns of autotrophic and heterotrophic picoplankton described here. 


\section{Conclusion}

468 This work presents different vertical segregation of the picoplanktonic groups surveyed.

469 Synechococcus and LNA heterotrophic prokaryotes tended to occupy shallower layers than

470 Prochlorococcus, picoeukaryotes and HNA heterotrophic prokaryotes. Seasonality was clearly

471 depicted by the two genera of cyanobacteria, with Synechococcus exceeding Prochlorococcus

472 cell numbers in early winter and late fall. Picoeukaryotes also tended to be more abundant in

473 winter and fall, contributing to a seasonal structuring of picophytoplankton in Red Sea waters

474 similar to higher latitude ecosystems. The seasonal patterns of heterotrophic prokaryotes were

475 less noticeable than those of picophytoplankton and we failed to find clear evidence of higher

476 biomass of picoplanktonic heterotrophs at the study site. Although the vertical gradients in

477 environmental conditions had a major effect on the distribution of autotrophic and heterotrophic

478 picoplankton, temporal changes over the year emerged as an important feature to be considered

479 in future studies of the Red Sea pelagic ecosystem. 


\section{Acknowledgements}

481 We gratefully acknowledge the crew of the RVs Thuwal and KAUST Explorer and all 482 the personnel from the Coastal and Marine Resources Core Lab for their diligent field-work

483 assistance. Miguel Viegas aided enormously with fieldwork and sample collection, and he was 484 also responsible for chlorophyll analysis. 
485

486

487

488

489

490

491

492

493

494

495

496

497

498

499

500

501

502

503

504

505

506

507

508

509

510

511

512

513

514

515

516

517

518

519

520

521

522

523

524

525

526

527

528

529

530

531

532

\section{References}

Agustí S. 2004. Viability and niche segregation of Prochlorococcus and Synechococcus cells across the Central Atlantic Ocean. Aquatic microbial ecology 36:53-59.

Agustí S, Lubián LM, Moreno-Ostos E, Estrada M, and Duarte CM. 2018. Projected Changes in Photosynthetic Picoplankton in a Warmer Subtropical Ocean. Frontiers in Marine Science 5:506.

Al-Najjar T, Badran MI, Richter C, Meyerhoefer M, and Sommer U. 2007. Seasonal dynamics of phytoplankton in the Gulf of Aqaba, Red Sea. Hydrobiologia 579:69-83.

Azam F. 1998. Microbial control of oceanic carbon flux: The plot thickens. Science 280:694-696. DOI 10.1126/science.280.5364.694

Berninger U-G, and Wickham SA. 2005. Response of the microbial food web to manipulation of nutrients and grazers in the oligotrophic Gulf of Aqaba and northern Red Sea. Marine biology 147:1017-1032.

Biddanda B, Ogdahl M, and Cotner J. 2001. Dominance of bacterial metabolism in oligotrophic relative to eutrophic waters. Limnology and Oceanography 46:730-739.

Biller SJ, Berube PM, Lindell D, and Chisholm SW. 2015. Prochlorococcus: the structure and function of collective diversity. Nat Rev Microbiol 13:13-27. 10.1038/nrmicro3378

Bock N, Van Wambeke F, Dion M, and Duhamel S. 2018. Microbial community structure in the western tropical South Pacific. Biogeosciences 15:3909-3925. 10.5194/bg-15-3909-2018

Boelen P, de Boer MK, Kraay GW, Veldhuis MJW, and Buma AGJ. 2000. UVBR-induced DNA damage in natural marine picoplankton assemblages in the tropical Atlantic Ocean. Marine Ecology Progress Series 193:1-9. DOI 10.3354/meps193001

Boelen P, Post AF, Veldhuis MJW, and Buma AGJ. 2002. Diel patterns of UVBR-induced DNA damage in picoplankton size fractions from the Gulf of Aqaba, Red Sea. Microbial Ecology 44:164-174. 10.1007/s00248-002-1002-7

Buck K, Chavez F, and Campbell L. 1996. Basin-wide distributions of living carbon components and the inverted trophic pyramid of the central gyre of the North Atlantic Ocean, summer 1993. Aquatic microbial ecology 10:283-298.

Bunse C, and Pinhassi J. 2017. Marine Bacterioplankton Seasonal Succession Dynamics. Trends Microbiol 25:494-505. 10.1016/j.tim.2016.12.013

Calbet A, Agersted MD, Kaartvedt S, Møhl M, Møller EF, Enghoff-Poulsen S, Paulsen ML, Solberg I, Tang KW, and Tönnesson K. 2015. Heterogeneous distribution of plankton within the mixed layer and its implications for bloom formation in tropical seas. Scientific reports 5:11240.

Calleja ML, Al-Otaibi N, and Moran XAG. 2019. Dissolved organic carbon contribution to oxygen respiration in the central Red Sea. Sci Rep 9:4690. 10.1038/s41598-019-40753-w

Calleja ML, Ansari MI, Rostad A, Silva L, Kaartvedt S, Irigoien X, and Moran XAG. 2018. The Mesopelagic Scattering Layer: A Hotspot for Heterotrophic Prokaryotes in the Red Sea Twilight Zone. Frontiers in Marine Science 5. UNSP 259

10.3389/fmars.2018.00259

Calvo-Díaz A, and Morán XAG. 2006. Seasonal dynamics of picoplankton in shelf waters of the southern Bay of Biscay. Aquatic microbial ecology 42:159-174.

Campbell L, Liu H, Nolla HA, and Vaulot D. 1997. Annual variability of phytoplankton and bacteria in the subtropical North Pacific Ocean at Station ALOHA during the 1991-1994 ENSO event. Deep Sea Research Part I: Oceanographic Research Papers 44:167-192.

Campbell L, and Vaulot D. 1993. Photosynthetic picoplankton community structure in the subtropical North Pacific Ocean near Hawaii (station ALOHA). Deep Sea Research Part I: Oceanographic Research Papers 40:2043-2060. 
533

534

535

536

537

538

539

540

541

542

543

544

545

546

547

548

549

550

551

552

553

554

555

556

557

558

559

560

561

562

563

564

565

566

567

568

569

570

571

572

573

574

575

576

577

578

579

580

581

582

Carlson CA, Ducklow HW, and Sleeter TD. 1996. Stocks and dynamics of bacterioplankton in the northwestern Sargasso Sea. Deep-Sea Research Part li-Topical Studies in Oceanography 43:491-515. Doi 10.1016/0967-0645(95)00101-8

Chaidez V, Dreano D, Agusti S, Duarte CM, and Hoteit I. 2017. Decadal trends in Red Sea maximum surface temperature. Scientific reports 7. ARTN 8144

10.1038/s41598-017-08146-z

Chen B, Wang L, Song S, Huang B, Sun J, and Liu H. 2011. Comparisons of picophytoplankton abundance, size, and fluorescence between summer and winter in northern South China Sea. Continental Shelf Research 31:1527-1540.

Cho BC, and Azam F. 1990. Biogeochemical significance of bacterial biomass in the ocean's euphotic zone. Marine ecology progress series Oldendorf 63:253-259.

Cottrell MT, and Kirchman DL. 2009. Photoheterotrophic Microbes in the Arctic Ocean in Summer and Winter. Applied and Environmental Microbiology 75:4958-4966. 10.1128/Aem.00117-09

Del Giorgio PA, Cole JJ, and Cimbleris A. 1997. Respiration rates in bacteria exceed phytoplankton production in unproductive aquatic systems. Nature 385:148.

DuRand MD, Olson RJ, and Chisholm SW. 2001. Phytoplankton population dynamics at the Bermuda Atlantic Time-series station in the Sargasso Sea. Deep Sea Research Part II: Topical Studies in Oceanography 48:1983-2003.

García FC, Calleja ML, Al-Otaibi N, Røstad A, and Morán XAG. 2018. Diel dynamics and coupling of heterotrophic prokaryotes and dissolved organic matter in epipelagic and mesopelagic waters of the central Red Sea. Environmental microbiology 20:2990-3000. 10.1111/1462-2920.14336

García-Martín EE, Daniels CJ, Davidson K, Davis CE, Mahaffey C, Mayers KMJ, McNeill S, Poulton AJ, Purdie DA, Tarran GA, and Robinson C. 2019a. Seasonal changes in plankton respiration and bacterial metabolism in a temperate shelf sea. Progress in oceanography 177. 10.1016/j.pocean.2017.12.002

García-Martín EE, Daniels CJ, Davidson K, Lozano J, Mayers KMJ, McNeill S, Mitchell E, Poulton AJ, Purdie DA, Tarran GA, Whyte C, and Robinson C. 2019b. Plankton community respiration and bacterial metabolism in a North Atlantic Shelf Sea during spring bloom development (April 2015). Progress in oceanography 177. ARTN 101873

10.1016/j.pocean.2017.11.002

Gasol JM, Del Giorgio PA, and Duarte CM. 1997. Biomass distribution in marine planktonic communities. Limnology and Oceanography 42:1353-1363.

Gasol JM, and Morán XAG. 2016. Flow Cytometric Determination of Microbial Abundances and Its Use to Obtain Indices of Community Structure and Relative Activity. In: McGenity TJ, Timmis KN, and Nogales B, eds. Hydrocarbon and Lipid Microbiology Protocols: SingleCell and Single-Molecule Methods. Berlin, Heidelberg: Springer Berlin Heidelberg, 159187.

Gasol JM, Zweifel UL, Peters F, Fuhrman JA, and Hagström Å. 1999. Significance of size and nucleic acid content heterogeneity as measured by flow cytometry in natural planktonic bacteria. Appl Environ Microbiol 65:4475-4483.

Giovannoni SJ, and Vergin KL. 2012. Seasonality in ocean microbial communities. Science 335:671-676. 10.1126/science.1198078

Gonzalez JM, Sherr EB, and Sherr BF. 1990. Size-Selective Grazing on Bacteria by Natural Assemblages of Estuarine Flagellates and Ciliates. Applied and Environmental Microbiology 56:583-589.

Gundersen K, Heldal M, Norland S, Purdie DA, and Knap AH. 2002. Elemental C, N, and P cell content of individual bacteria collected at the Bermuda Atlantic Time-series Study (BATS) site. Limnology and Oceanography 47:1525-1530.

Peer) reviewing PDF | (2019:07:39703:2:0:NEW 13 Jan 2020) 
583

584

585

586

587

588

589

590

591

592

593

594

595

596

597

598

599

600

601

602

603

604

605

606

607

608

609

610

611

612

613

614

615

616

617

618

619

620

621

622

623

624

625

626

627

628

629

630

631

632

633

Harris LA, Duarte CM, and Nixon SW. 2006. Allometric laws and prediction in estuarine and coastal ecology. Estuaries and Coasts 29:340-344.

Iversen KR, and Seuthe L. 2011. Seasonal microbial processes in a high-latitude fjord (Kongsfjorden, Svalbard): I. Heterotrophic bacteria, picoplankton and nanoflagellates. Polar Biology 34:731-749. 10.1007/s00300-010-0929-2

Karner MB, DeLong EF, and Karl DM. 2001. Archaeal dominance in the mesopelagic zone of the Pacific Ocean. Nature 409:507-510. 10.1038/35054051

Kirkham AR, Lepere C, Jardillier LE, Not F, Bouman H, Mead A, and Scanlan DJ. 2013. A global perspective on marine photosynthetic picoeukaryote community structure. ISME J 7:922-936. 10.1038/ismej.2012.166

Lara E, Vaque D, Sa EL, Boras JA, Gomes A, Borrull E, Diez-Vives C, Teira E, Pernice MC, Garcia FC, Forn I, Castillo YM, Peiro A, Salazar G, Moran XAG, Massana R, Catala TS, Luna GM, Agusti S, Estrada M, Gasol JM, and Duarte CM. 2017. Unveiling the role and life strategies of viruses from the surface to the dark ocean. Science Advances 3. ARTN e1602565

10.1126/sciadv. 1602565

Lefort T, and Gasol JM. 2014. Short-time scale coupling of picoplankton community structure and single-cell heterotrophic activity in winter in coastal NW Mediterranean Sea waters. Journal of Plankton Research 36:243-258. 10.1093/plankt/fbt073

Li W, Jellett J, and Dickie P. 1995. DNA distributions in planktonic bacteria stained with TOTO or TO-PRO. Limnology and Oceanography 40:1485-1495.

Li WKW. 1998. Annual average abundance of heterotrophic bacteria and Synechococcus in surface ocean waters. Limnology and Oceanography 43:1746-1753. DOI 10.4319/lo.1998.43.7.1746

Li WKW. 2009. From cytometry to macroecology: a quarter century quest in microbial oceanography. Aquatic microbial ecology 57:239-251. 10.3354/ame01328

Lindell D, and Post AF. 1995. Ultraphytoplankton Succession Is Triggered by Deep Winter Mixing in the Gulf-of-Aqaba (Eilat), Red-Sea. Limnology and Oceanography 40:11301141.

López-Sandoval DC, Delgado-Huertas A, Carrillo-de-Albornoz P, Duarte CM, and Agustí S. 2019. Use of cavity ring-down spectrometry to quantify 13C-primary productivity in oligotrophic waters. Limnology and Oceanography: Methods 17:137-144.

Malmstrom RR, Coe A, Kettler GC, Martiny AC, Frias-Lopez J, Zinser ER, and Chisholm SW. 2010. Temporal dynamics of Prochlorococcus ecotypes in the Atlantic and Pacific oceans. ISME J 4:1252-1264. 10.1038/ismej.2010.60

Monier A, Chambouvet A, Milner DS, Attah V, Terrado R, Lovejoy C, Moreau H, Santoro AE, Derelle E, and Richards TA. 2017. Host-derived viral transporter protein for nitrogen uptake in infected marine phytoplankton. Proc Natl Acad Sci U S A 114:E7489-E7498. 10.1073/pnas.1708097114

Moran XAG. 2007. Annual cycle of picophytoplankton photosynthesis and growth rates in a temperate coastal ecosystem: a major contribution to carbon fluxes. Aquatic microbial ecology 49:267-279. 10.3354/ame01151

Morán XAG, Bode A, Suárez LÁ, and Nogueira E. 2007. Assessing the relevance of nucleic acid content as an indicator of marine bacterial activity. Aquatic microbial ecology 46:141-152.

Morán XAG, Fernández E, and Pérez V. 2004. Size-fractionated primary production, bacterial production and net community production in subtropical and tropical domains of the oligotrophic NE Atlantic in autumn. Marine Ecology Progress Series 274:17-29.

Ngugi DK, Antunes A, Brune A, and Stingl U. 2012. Biogeography of pelagic bacterioplankton across an antagonistic temperature-salinity gradient in the Red Sea. Molecular Ecology 21:388-405. 10.1111/j.1365-294X.2011.05378.x

Peer) reviewing PDF | (2019:07:39703:2:0:NEW 13 Jan 2020) 
634

635

636

637

638

639

640

641

642

643

644

645

646

647

648

649

650

651

652

653

654

655

656

657

658

659

660

661

662

663

664

665

666

667

668

669

670

671

672

673

674

675

676

677

678

679

680

681

682

Nishimura Y, Kim C, and Nagata T. 2005. Vertical and seasonal variations of bacterioplankton subgroups with different nucleic Acid contents: possible regulation by phosphorus. Appl Environ Microbiol 71:5828-5836. 10.1128/AEM.71.10.5828-5836.2005

Olson RJ, Chisholm SW, Zettler ER, Altabet MA, and Dusenberry JA. 1990. Spatial and temporal distributions of prochlorophyte picoplankton in the North Atlantic Ocean. Deep Sea Research Part A Oceanographic Research Papers 37:1033-1051.

Partensky F, Hess WR, and Vaulot D. 1999. Prochlorococcus, a marine photosynthetic prokaryote of global significance. Microbiol Mol Biol Rev 63:106-127.

Pearman JK, Ellis J, Irigoien X, Sarma YVB, Jones BH, and Carvalho S. 2017. Microbial planktonic communities in the Red Sea: high levels of spatial and temporal variability shaped by nutrient availability and turbulence. Scientific reports 7. ARTN 6611

10.1038/s41598-017-06928-z

Post AF, Penno S, Zandbank K, Paytan A, Huse S, and Mark Welch D. 2011. Long term seasonal dynamics of Synechococcus population structure in the Gulf of Aqaba, Northern Red Sea. Frontiers in microbiology 2:131.

Qian PY, Wang Y, Lee OO, Lau SCK, Yang J, Lafi FF, Al-Suwailem A, and Wong TYH. 2011. Vertical stratification of microbial communities in the Red Sea revealed by 16S rDNA pyrosequencing (vol 5, pg 507, 2010). Isme Journal 5:568-568. 10.1038/ismej.2010.159

Qurban MAB, Wafar M, and Heinle M. 2019. Phytoplankton and Primary Production in the Red Sea. In: Rasul NMA, and Stewart ICF, eds. Oceanographic and Biological Aspects of the Red Sea. Cham: Springer International Publishing, 491-506.

Rabouille S, Edwards CA, and Zehr JP. 2007. Modelling the vertical distribution of Prochlorococcus and Synechococcus in the North Pacific Subtropical Ocean. Environmental microbiology 9:2588-2602. 10.1111/j.1462-2920.2007.01376.x

Ramette A. 2007. Multivariate analyses in microbial ecology. Fems Microbiology Ecology 62:142-160. 10.1111/j.1574-6941.2007.00375.x

Rasul NM, Stewart IC, and Nawab ZA. 2015. Introduction to the Red Sea: its origin, structure, and environment. The Red Sea: Springer, 1-28.

Regaudie-de-Gioux A, and Duarte CM. 2013. Global patterns in oceanic planktonic metabolism. Limnology and Oceanography 58:977-986. 10.4319/lo.2013.58.3.0977

Ribeiro CGE, Marie D, dos Santos AL, Brandini FP, and Vaulot D. 2016. Estimating microbial populations by flow cytometry: Comparison between instruments. Limnology and Oceanography-Methods 14:750-758. 10.1002/lom3.10135

Rivkin RB. 1991. Seasonal Patterns of Planktonic Production in Mcmurdo Sound, Antarctica. American Zoologist 31:5-16.

Røstad A, Kaartvedt S, and Aksnes DL. 2016. Light comfort zones of mesopelagic acoustic scattering layers in two contrasting optical environments. Deep Sea Research Part I: Oceanographic Research Papers 113:1-6. https://doi.org/10.1016/j.dsr.2016.02.020

Sherr EB, Sherr BF, and Longnecker K. 2006. Distribution of bacterial abundance and cellspecific nucleic acid content in the Northeast Pacific Ocean. Deep Sea Research Part I: Oceanographic Research Papers 53:713-725.

Shibl AA, Haroon MF, Ngugi DK, Thompson LR, and Stingl U. 2016. Distribution of Prochlorococcus Ecotypes in the Red Sea Basin Based on Analyses of rpoC1 Sequences. Frontiers in Marine Science 3. UNSP 104

10.3389/fmars.2016.00104

Silva L, Calleja ML, Huete-Stauffer TM, Ivetic S, Ansari MI, Viegas M, and Moran XAG. 2019. Low Abundances but High Growth Rates of Coastal Heterotrophic Bacteria in the Red Sea. Frontiers in microbiology 9. ARTN 3244

10.3389/fmicb.2018.03244

Peer) reviewing PDF | (2019:07:39703:2:0:NEW 13 Jan 2020) 
683

684

685

686

687

688

689

690

691

692

693

694

695

696

697

698

699

700

701

702

703

704

705

706

707

708

709

710

711

712

713

714

715

716

717

718

719

720

721

722

723

Sommer U. 2000. Scarcity of medium-sized phytoplankton in the northern Red Sea explained by strong bottom-up and weak top-down control. Marine Ecology Progress Series 197:19-25.

Sommer U, Berninger UG, Böttger-Schnack R, Cornils A, Hagen W, Hansen T, Al-Najjar T, Post $A F$, Schnack-Schiel SB, and Stibor H. 2002. Grazing during early spring in the Gulf of Aqaba and the northern Red Sea. Marine Ecology Progress Series 239:251-261.

Tesfamichael D, and Pauly D. 2016. The Red Sea ecosystem and fisheries: Springer.

Thompson LR, Williams GJ, Haroon MF, Shibl A, Larsen P, Shorenstein J, Knight R, and Stingl U. 2017. Metagenomic covariation along densely sampled environmental gradients in the Red Sea. ISME J 11:138-151. 10.1038/ismej.2016.99

van den Engh GJ, Doggett JK, Thompson AW, Doblin MA, Gimpel CNG, and Karl DM. 2017. Dynamics of Prochlorococcus and Synechococcus at Station ALOHA Revealed through Flow Cytometry and High-Resolution Vertical Sampling. Frontiers in Marine Science 4. UNSP 359

10.3389/fmars.2017.00359

Waleron M, Waleron K, Vincent WF, and Wilmotte A. 2007. Allochthonous inputs of riverine picocyanobacteria to coastal waters in the Arctic Ocean. Fems Microbiology Ecology 59:356-365. 10.1111/j.1574-6941.2006.00236.x

Wei YQ, Sun J, Zhang XD, Wang J, and Huang K. 2019. Picophytoplankton size and biomass around equatorial eastern Indian Ocean. Microbiologyopen 8. ARTN e629

$10.1002 / \mathrm{mbo3} .629$

Worden AZ, Nolan JK, and Palenik B. 2004. Assessing the dynamics and ecology of marine picophytoplankton: the importance of the eukaryotic component. Limnology and Oceanography 49:168-179.

Zhang Y, Jiao NZ, and Hong N. 2008. Comparative study of picoplankton biomass and community structure in different provinces from subarctic to subtropical oceans. DeepSea Research Part li-Topical Studies in Oceanography 55:1605-1614. 10.1016/.j.dsr2.2008.04.014

Zhu CS, and Yu JM. 2009. Nonmetric Multidimensional Scaling Corrects for Population Structure in Association Mapping With Different Sample Types. Genetics 182:875-888. 10.1534/genetics. 108.098863

Zubkov M, Allen J, and Fuchs B. 2004. Coexistence of dominant groups in marine bacterioplankton community - a combination of experimental and modelling approaches. Journal of the Marine Biological Association of the United Kingdom 84:519-529.

Zubkov MV, Sleigh MA, Burkill PH, and Leakey RJ. 2000. Picoplankton community structure on the Atlantic Meridional Transect: a comparison between seasons. Progress in oceanography 45:369-386.

Zwirglmaier K, Heywood JL, Chamberlain K, Woodward EM, Zubkov MV, and Scanlan DJ. 2007. Basin-scale distribution patterns of picocyanobacterial lineages in the Atlantic Ocean. Environ Microbiol 9:1278-1290. 10.1111/j.1462-2920.2007.01246.x

Peer) reviewing PDF | (2019:07:39703:2:0:NEW 13 Jan 2020) 
Figure 1

Mean seasonal vertical profiles of environmental variables.

(A) temperature, (B) salinity, (C) dissolved inorganic nitrogen (nitrate + nitrite, DIN), (D) dissolved inorganic phosphorus (DIP), (E) dissolved organic carbon (DOC), and (F) chlorophyll a (Chl a) concentrations in winter (blue line with circle symbol), spring (turquoise line with square symbol), summer (pink line with triangle symbol) and fall (orange line with star symbol) at the study station. Error bars show the standard error of the mean. The shaded area in (F) indicates the overall range of the deep chlorophyll maximum (DCM). See the text for details.
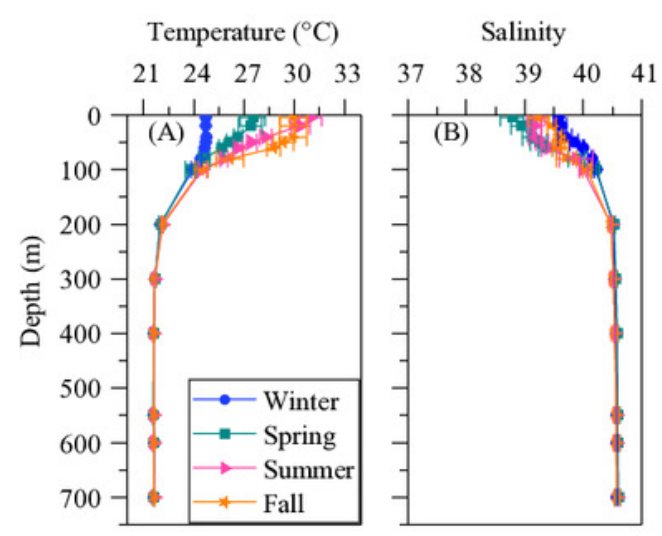

$\left.\operatorname{DIN}(\mu \mathrm{mol} \mathrm{L})^{-1}\right)$

DIP $\left.(\mu \mathrm{mol} \mathrm{L})^{-1}\right)$

$\left.\operatorname{DOC}(\mu \mathrm{mol} \mathrm{L})^{-1}\right)$

Chl $a\left(\mu \mathrm{g} \mathrm{L}^{-1}\right)$

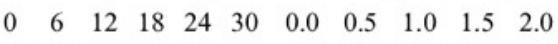

$\begin{array}{lllll}48 & 56 & 64 & 72 & 80\end{array}$ $\begin{array}{lllll}0.0 & 0.1 & 0.2 & 0.3 & 0.4\end{array}$
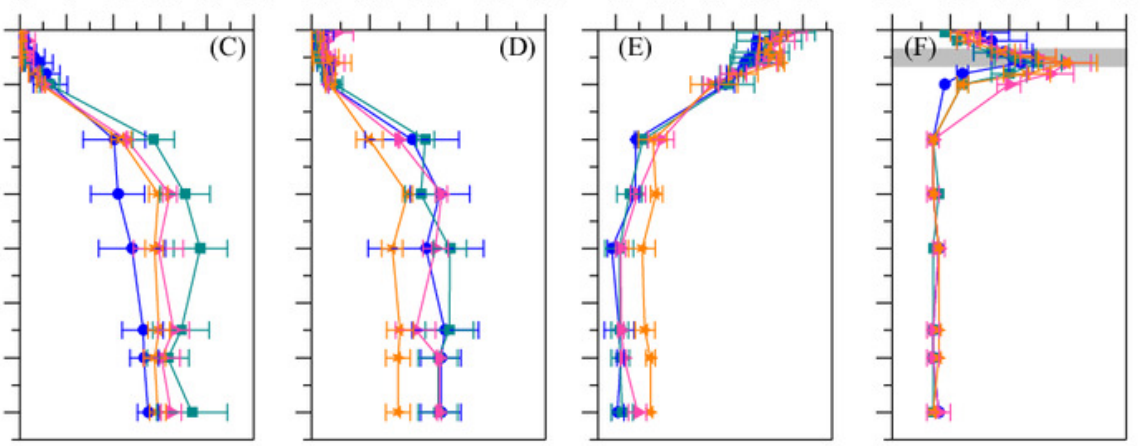


\section{Figure 2}

Mean seasonal values of total and size-fractionated chlorophyll a concentration.

(A) total integrated chlorophyll a ( $\mathrm{T}-\mathrm{Chl}$ a) concentration and (B) mean contributions of the three size-fractions in the upper $100 \mathrm{~m}$ of the study station. $\mathrm{pChl} \mathrm{a} \mathrm{:} \mathrm{picoplankton,} \mathrm{nChl} \mathrm{a} \mathrm{:}$ nanoplankton and $\mathrm{mChl} \mathrm{a} \mathrm{:} \mathrm{microplankton.}$
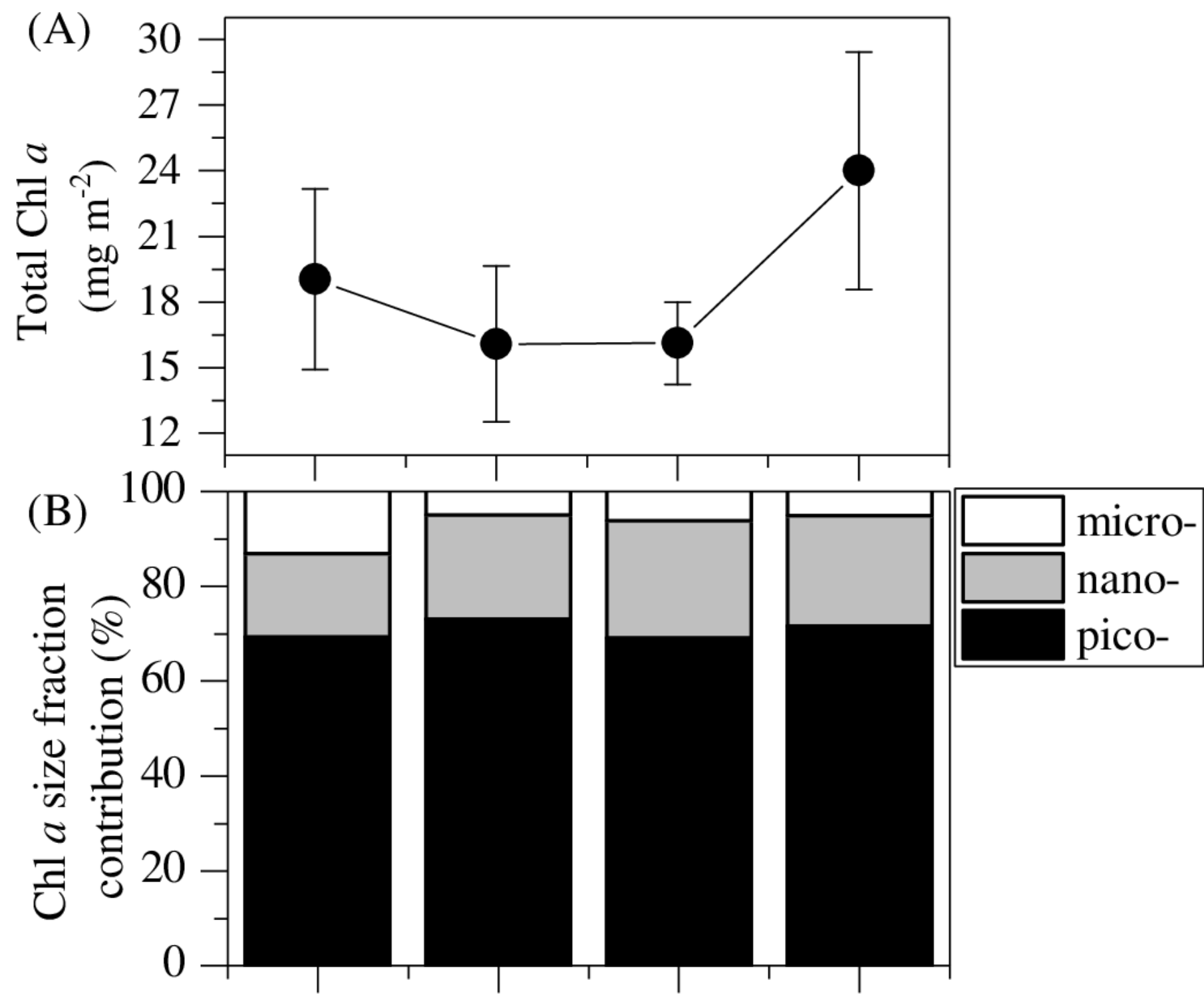

Winter Spring Summer Fall 
Figure 3

Vertical distribution of autotrophic picoplankton mean seasonal abundance and cellular characteristics.

(A-E) abundance, (F-J) biovolume,(K-O) relative red fluorescence of Prochlorococcus, low (LFSyn) and high (HF-Syn) phycoerythrin fluorescence populations of Synechococcus and small and large picoeukaryotes in winter (blue line with circle symbol), spring (turquoise line with square symbol), summer (pink line with triangle symbol) and fall (orange line with star symbol) at the study station. Error bars show the standard error of the mean. The shaded area indicates the overall range of the DCM.
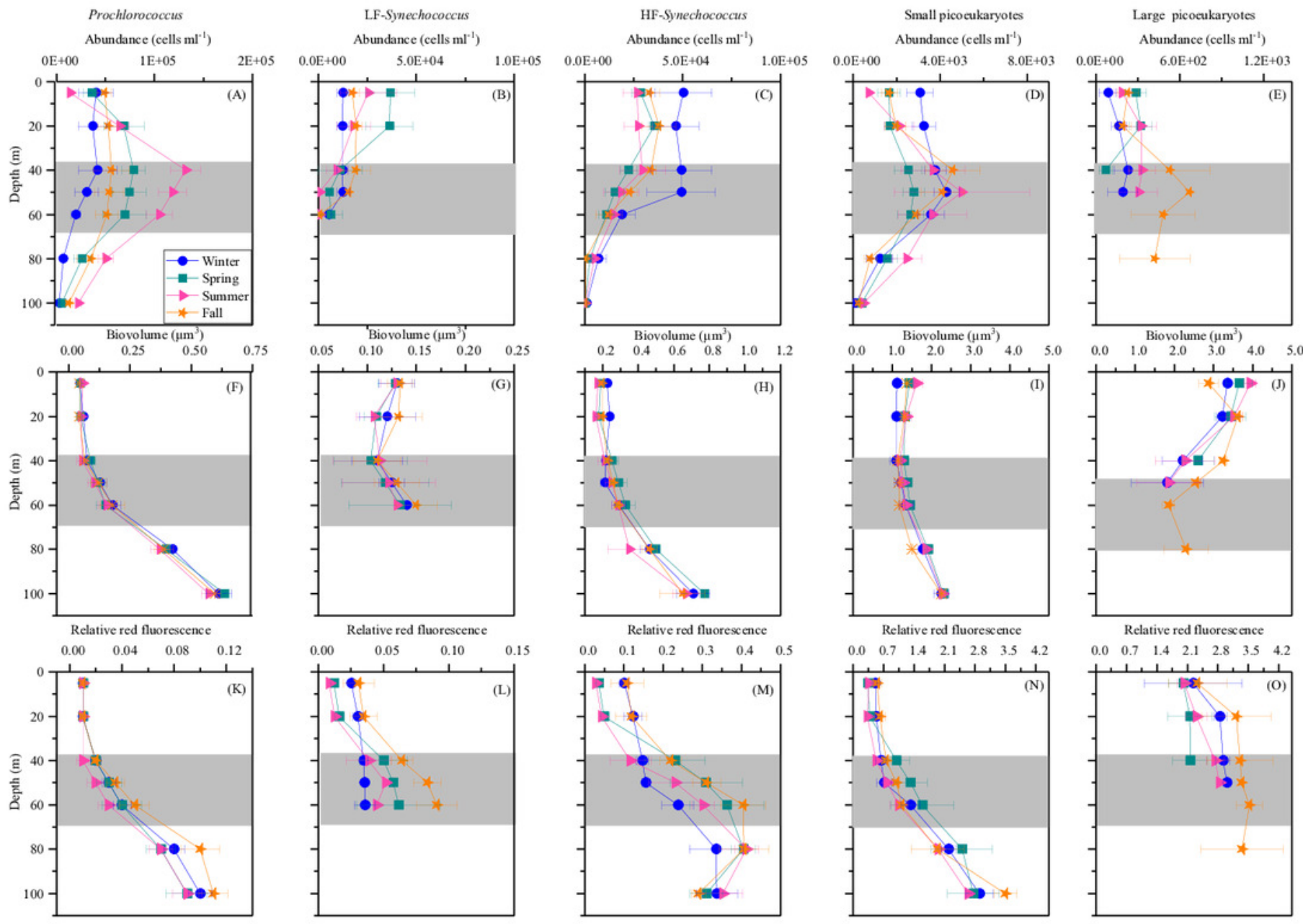


\section{Figure 4}

Vertical distribution of heterotrophic prokaryotes mean seasonal abundance and biovolume.

Abundance of LNA (A) and (B) HNA cells, (C) contribution of HNA cells to total numbers (\%HNA) and biovolume of LNA (D) and HNA (E) cells in winter (blue line with circle symbol), spring (turquoise line with square symbol), summer (pink line with triangle symbol) and fall (orange line with star symbol) at the study station. Error bars show the standard error of the mean. The shaded area indicates the overall range of the DCM. 


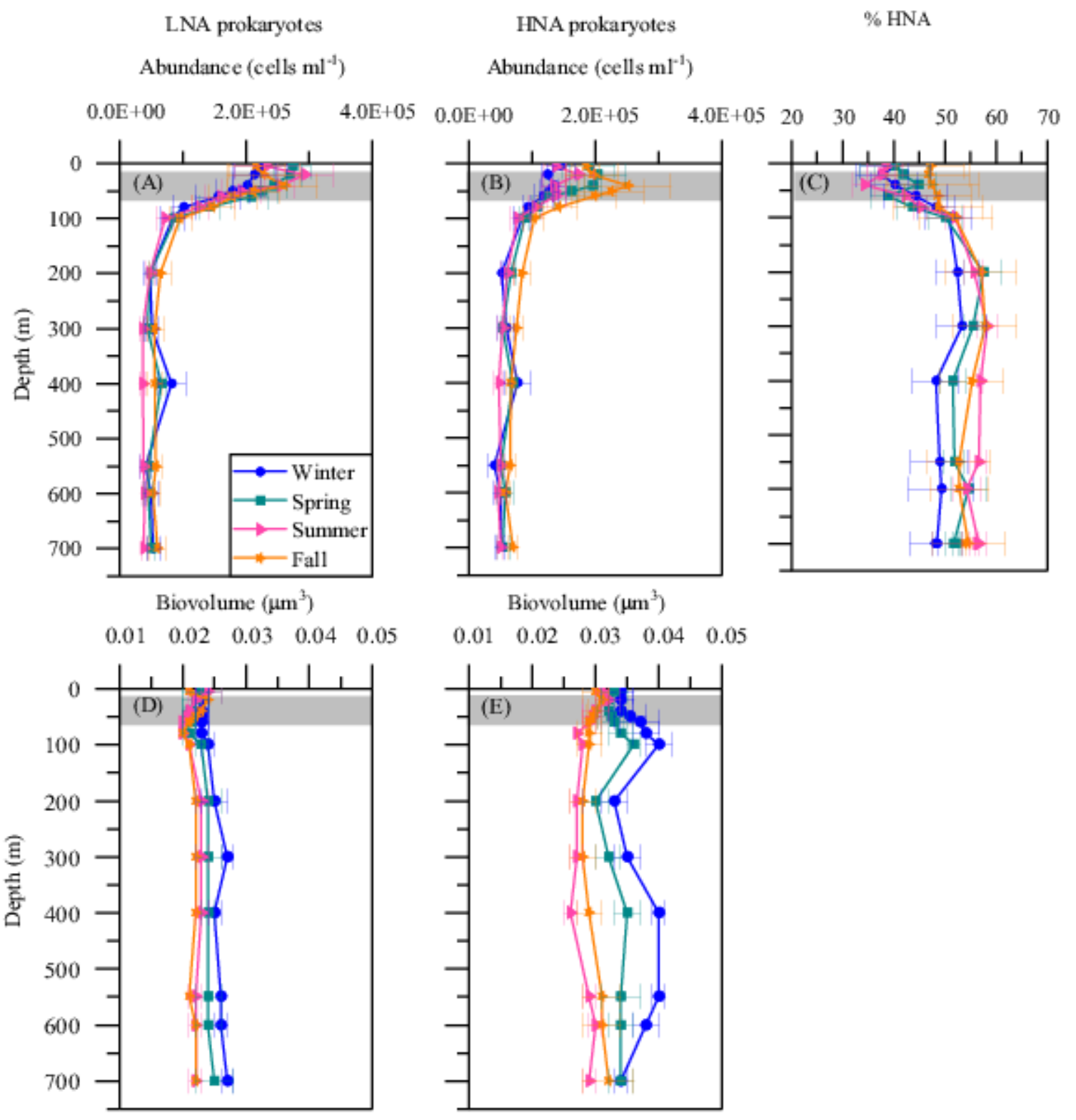


Figure 5

Temporal variability of autotrophic picoplankton abundances averaged for the upper $100 \mathrm{~m}$.

(A) Prochlorococcus, (B) high (HF-Syn) and low fluorescence (LF-Syn) Synechococcus and (D) small (Speuk and large (Lpeuk) picoeukaryotes. Also shown in (C) the ratio between Prochlorococcus and Synechococcus cell abundances.
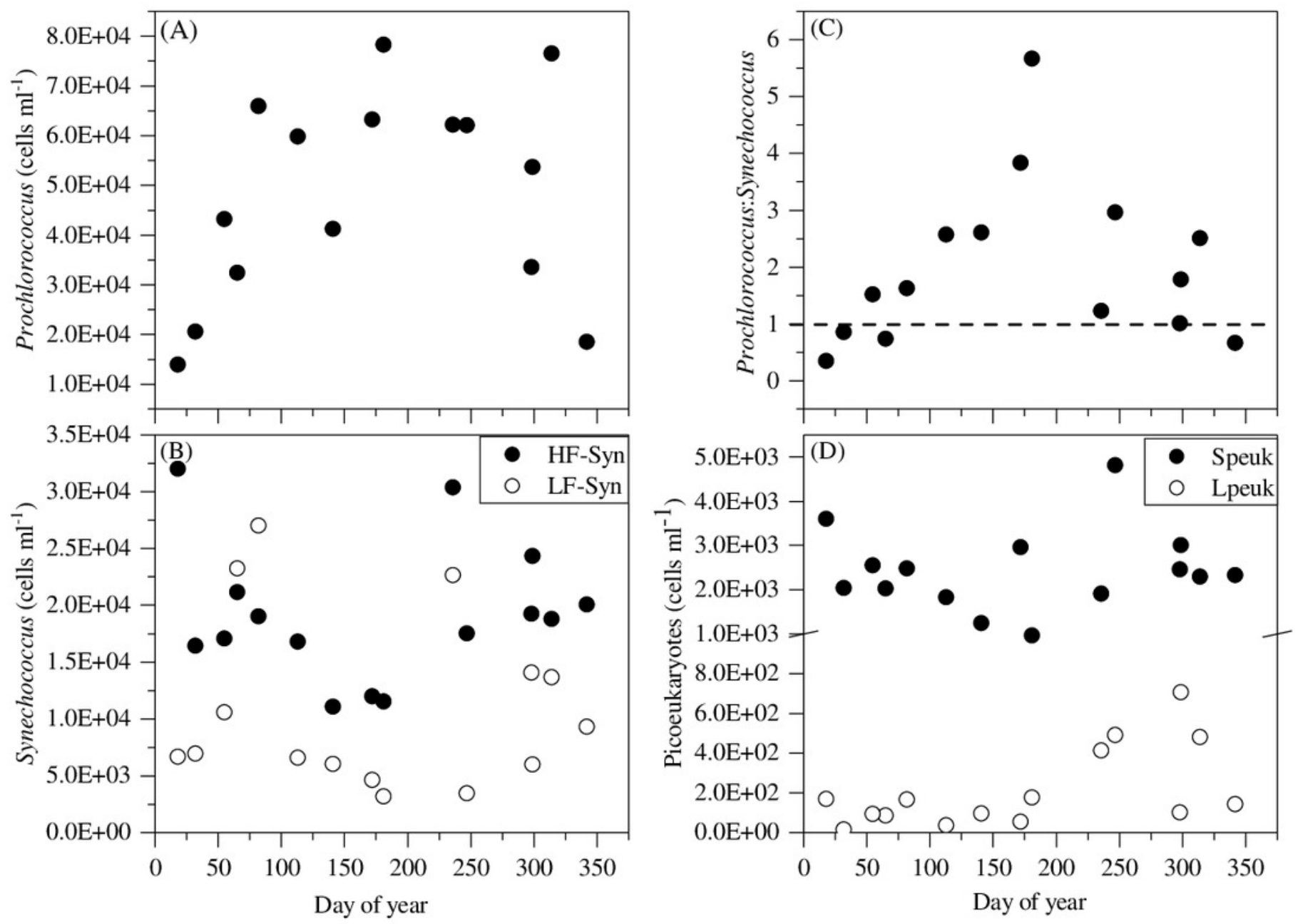
Figure 6

Temporal variability of heterotrophic prokaryotes abundances averaged for the upper $100 \mathrm{~m}$.

(A) low (LNA) and high (HNA) nucleic acid bacteria and (B) contribution of HNA cells to total numbers (\%HNA). 


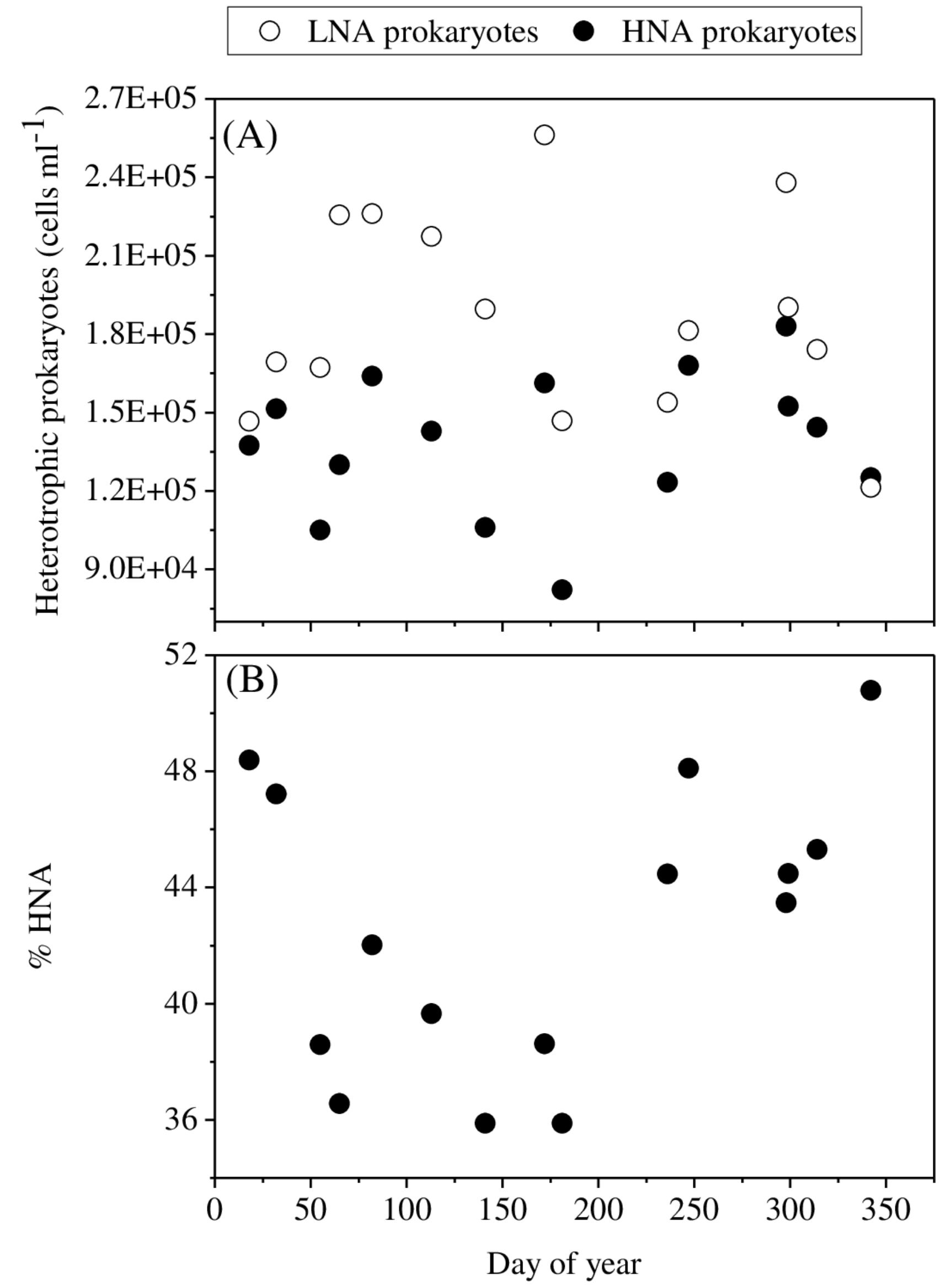




\section{Figure 7}

Mean seasonal values of autotrophic and heterotrophic picoplankton integrated biomass in winter, spring, summer and fall at the study station.

The green-yellow bar shows the integrated biomass for the upper $100 \mathrm{~m}$ of autotrophic picoplankton (Prochlorococcus (Pro), low (LF-Syn) and high (HF-Syn) phycoerythrin fluorescence populations of Synechococcus and small (Speuk) and large (Lpeuk) picoeukaryotes). The first black-gray bar shows the same for heterotrophic prokaryotes $(<100 \mathrm{~m})$ while the second black-gray bar shows the values integrated through the entire water column $(<700 \mathrm{~m})$. 


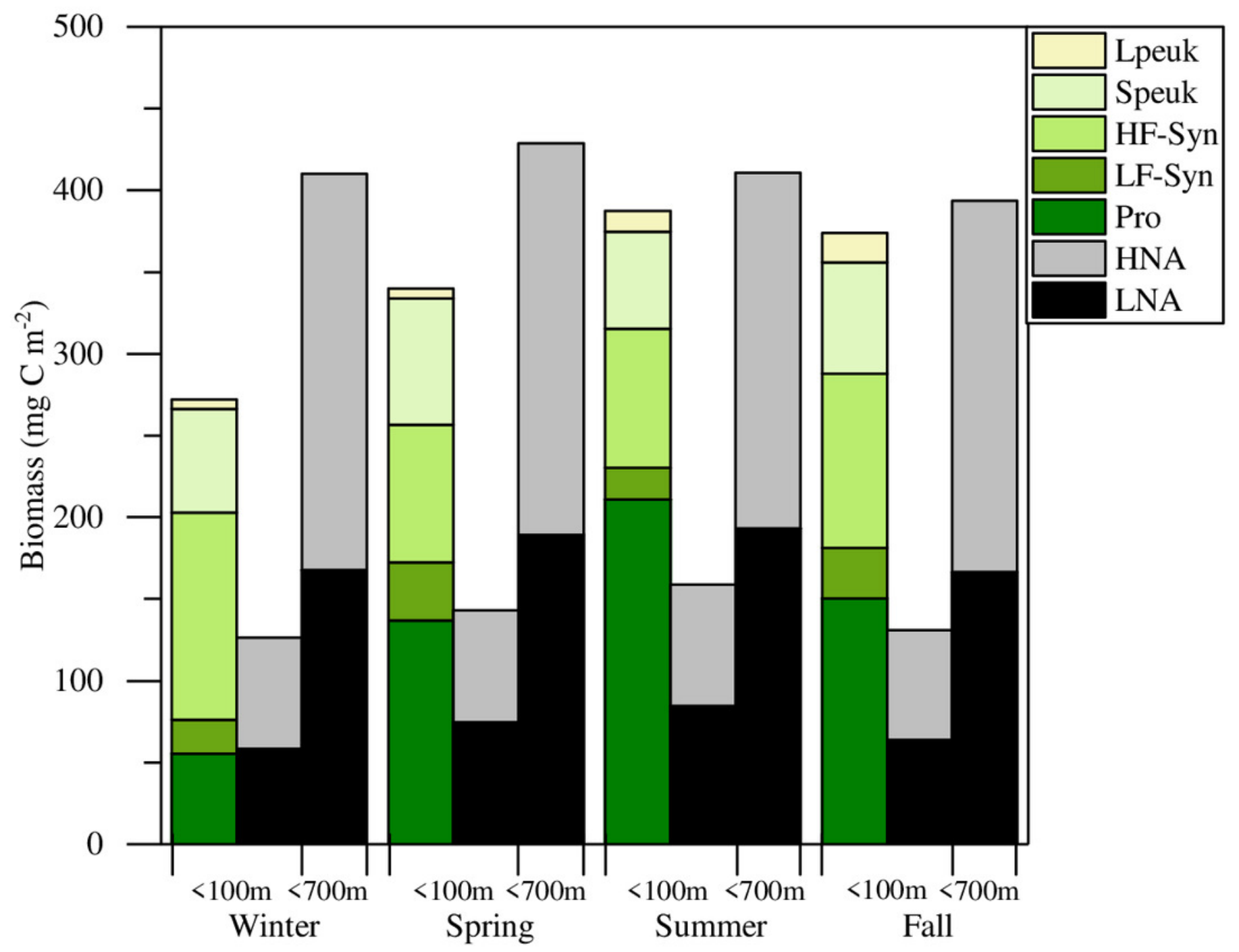




\section{Figure 8}

Nonmetric multidimensional scaling (NMDS) analysis of Bray-Curtis distances of the abundances of autotrophic and heterotrophic picoplankton and significant environmental variables in the upper epipelagic zone.

All samples were arranged by five depth categories (surface, above DCM, DCM, below DCM and $100 \mathrm{~m}$ ) and coupled to significant $(p<0.05)$ environmental variables: temperature (Tem), salinity (Sal), total chlorophyll a (T-Chl a), dissolved inorganic nitrogen (DIN) and dissolved organic nitrogen (DON) concentration. The centroids of the different populations (labeled in gray) indicate where each population was more abundant, and the vectors indicate the direction and strength of the environmental parameters. Group abbreviations as in Figs. 7 and in the main text. 


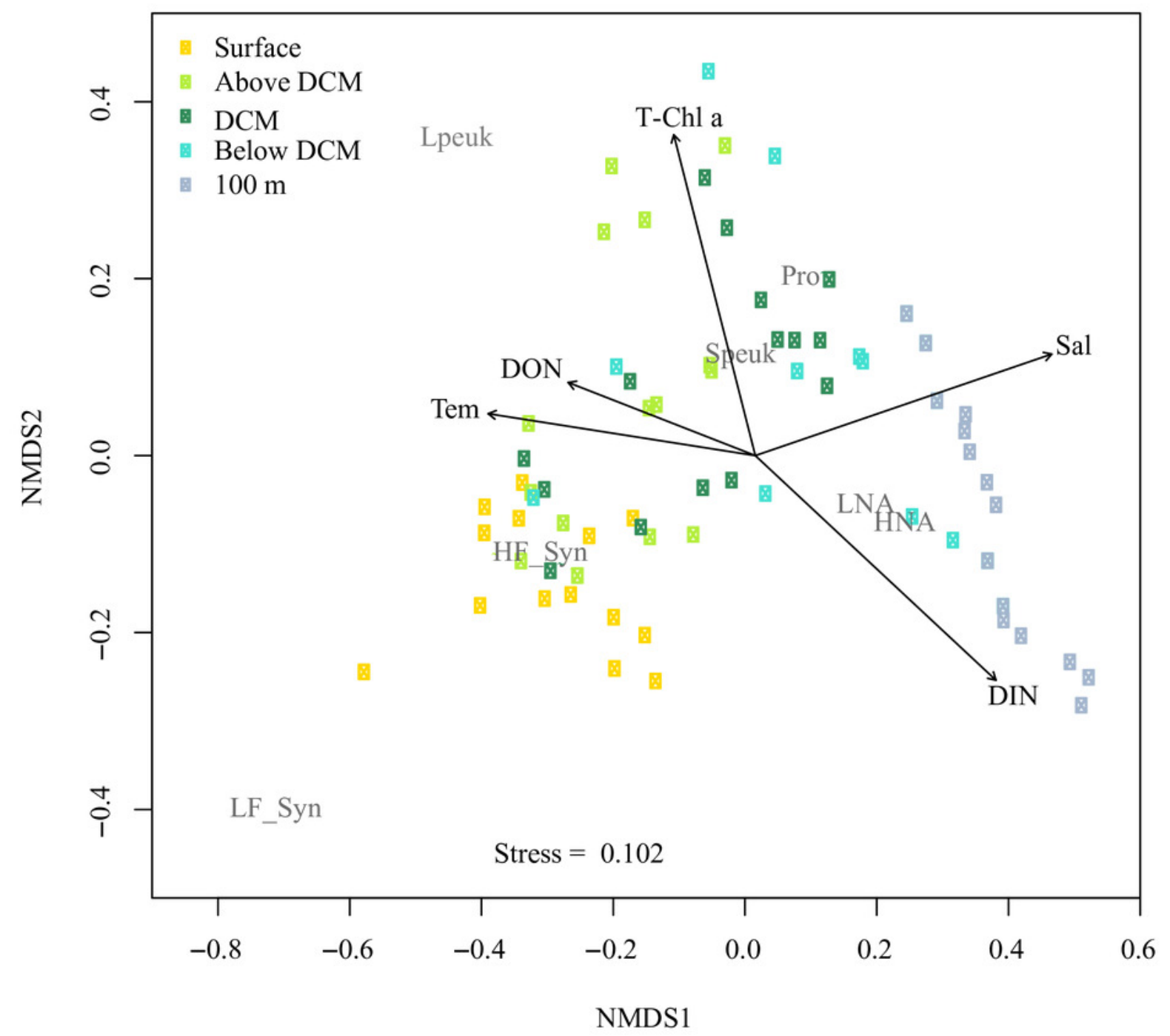




\section{Table $\mathbf{1}$ (on next page)}

Seasonal distribution and date of the 15 individual samplings at the study site, with the corresponding day of the year for the assessment of seasonal patterns. 


\begin{tabular}{ccc}
\hline Season & $\begin{array}{c}\text { Sampling date } \\
(\mathbf{d d} / \mathbf{m m} / \mathbf{y y y y})\end{array}$ & Day of year \\
Winter & $19 / 01 / 2015$ & 18 \\
& $02 / 02 / 2016$ & 32 \\
& $25 / 02 / 2017$ & 55 \\
\hline \multirow{3}{*}{ Spring } & $24 / 03 / 2015$ & 82 \\
& $06 / 03 / 2016$ & 65 \\
& $24 / 04 / 2017$ & 113 \\
& $5 / 22 / 2017$ & 141 \\
\hline \multirow{3}{*}{ Summer } & $01 / 07 / 2015$ & 181 \\
& $25 / 08 / 2015$ & 236 \\
& $05 / 09 / 2015$ & 247 \\
& $21 / 06 / 2016$ & 172 \\
\hline \multirow{5}{*}{ Fall } & $26 / 10 / 2015$ & 298 \\
& $11 / 11 / 2015$ & 314 \\
& $09 / 12 / 2015$ & 342 \\
& $10 / 26 / 2016$ & 299
\end{tabular}

3

4

5 


\section{Table 2 (on next page)}

Average seasonal values of environmental properties at the surface of the study site and characteristic depths (mean $\pm \mathrm{SE}$ ).

Sea surface temperature (SST), salinity, dissolved inorganic nitrogen (nitrate + nitrite, DIN), dissolved inorganic phosphorus (phosphate, DIP), dissolved organic carbon (DOC), total chlorophyll a concentration ( $\mathrm{Chl}$ a), stratification index (SI) and depths of the upper mixed layer (UML), the euphotic zone (Zph), the deep chlorophyll maximum (DCM) and the nutricline (NC). Stars and superscript letters indicate significant differences between seasons (ANOVA and Tukey post hoc test; $*, p=0.05 ; * * p=0.01 ;{ }^{* * *} p=0.001$. 


\begin{tabular}{|c|c|c|c|c|}
\hline & Winter & Spring & Summer & Fall \\
\hline SST $* * *$ & $24.7 \pm 0.1^{\mathrm{a}}$ & $27.5 \pm 0.7^{\mathrm{a}, \mathrm{c}}$ & $30.9 \pm 0.7^{b, c}$ & $29.9 \pm 0.8^{c}$ \\
\hline$\left({ }^{\circ} \mathrm{C}\right)$ & $\mathrm{n}=3$ & $\mathrm{n}=4$ & $\mathrm{n}=4$ & $\mathrm{n}=4$ \\
\hline \multirow{2}{*}{ Salinity } & $39.6 \pm 0.1$ & $38.8 \pm 0.2$ & $39.2 \pm 0.2$ & $39.2 \pm 0.2$ \\
\hline & $n=3$ & $\mathrm{n}=4$ & $\mathrm{n}=4$ & $\mathrm{n}=4$ \\
\hline \multirow{2}{*}{$\begin{array}{c}\text { DIN } \\
\left(\mu \mathrm{mol} \mathrm{l}^{-1}\right)\end{array}$} & $0.1 \pm 0.04$ & $0.2 \pm 0.1$ & $0.3 \pm 0.2$ & $0.2 \pm 0.1$ \\
\hline & $\mathrm{n}=2$ & $\mathrm{n}=4$ & $\mathrm{n}=2$ & $n=3$ \\
\hline \multirow{2}{*}{ 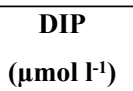 } & $0.1 \pm 0.1$ & $0.04 \pm 0.01$ & $0.2 \pm 0.1$ & $0.1 \pm 0.04$ \\
\hline & $\mathrm{n}=2$ & $\mathrm{n}=4$ & $\mathrm{n}=2$ & $n=3$ \\
\hline \multirow{2}{*}{$\begin{array}{c}\text { DOC } \\
\left(\mu \mathrm{mol} \mathrm{l}^{-1}\right)\end{array}$} & $75.8 \pm 1.4$ & $75.4 \pm 6.7$ & $77.7 \pm 2.9$ & $75.3 \pm 1.7$ \\
\hline & $\mathrm{n}=2$ & $\mathrm{n}=4$ & $n=4$ & $n=3$ \\
\hline \multirow{2}{*}{$\begin{array}{c}\text { Chl a } \\
\left(\mu \mathrm{gl}^{-1}\right)\end{array}$} & $0.15 \pm 0.05$ & $0.09 \pm 0.003$ & $0.13 \pm 0.02$ & $0.12 \pm 0.02$ \\
\hline & $\mathrm{n}=2$ & $\mathrm{n}=4$ & $\mathrm{n}=4$ & $\mathrm{n}=4$ \\
\hline \multirow{2}{*}{ SI } & $1.03 \pm 0.14$ & $2.68 \pm 0.52$ & $2.74 \pm 0.27$ & $2.39 \pm 0.26$ \\
\hline & $\mathrm{n}=2$ & $\mathrm{n}=4$ & $\mathrm{n}=4$ & $\mathrm{n}=4$ \\
\hline \multirow{2}{*}{$\begin{array}{c}\text { UML } * * * \\
\text { (m) }\end{array}$} & $60 \pm 7^{\mathrm{a}}$ & $43 \pm 2^{a}$ & $19 \pm 3^{b}$ & $48 \pm 5^{a}$ \\
\hline & $n=2$ & $\mathrm{n}=4$ & $n=4$ & $\mathrm{n}=4$ \\
\hline \multirow{2}{*}{ Zph (m) } & $85 \pm 1$ & $85 \pm 2$ & $76 \pm 4$ & $72 \pm 4$ \\
\hline & $\mathrm{n}=2$ & $n=3$ & $\mathrm{n}=4$ & $n=4$ \\
\hline \multirow{2}{*}{ DCM (m) } & $55 \pm 1$ & $62 \pm 8$ & $63 \pm 8$ & $44 \pm 12$ \\
\hline & $n=4$ & $\mathrm{n}=4$ & $\mathrm{n}=4$ & $\mathrm{n}=4$ \\
\hline \multirow{2}{*}{$\mathrm{NC}(\mathrm{m})$} & $63 \pm 7$ & $74 \pm 8$ & $47 \pm 35$ & $75 \pm 5$ \\
\hline & $n=2$ & $\mathrm{n}=4$ & $\mathrm{n}=2$ & $n=3$ \\
\hline
\end{tabular}

